Prepared in cooperation with Northern Arizona University and Utah State University

\title{
Monitoring Fine-Sediment Volume in the Colorado River Ecosystem, Arizona: Bathymetric Survey Techniques
}

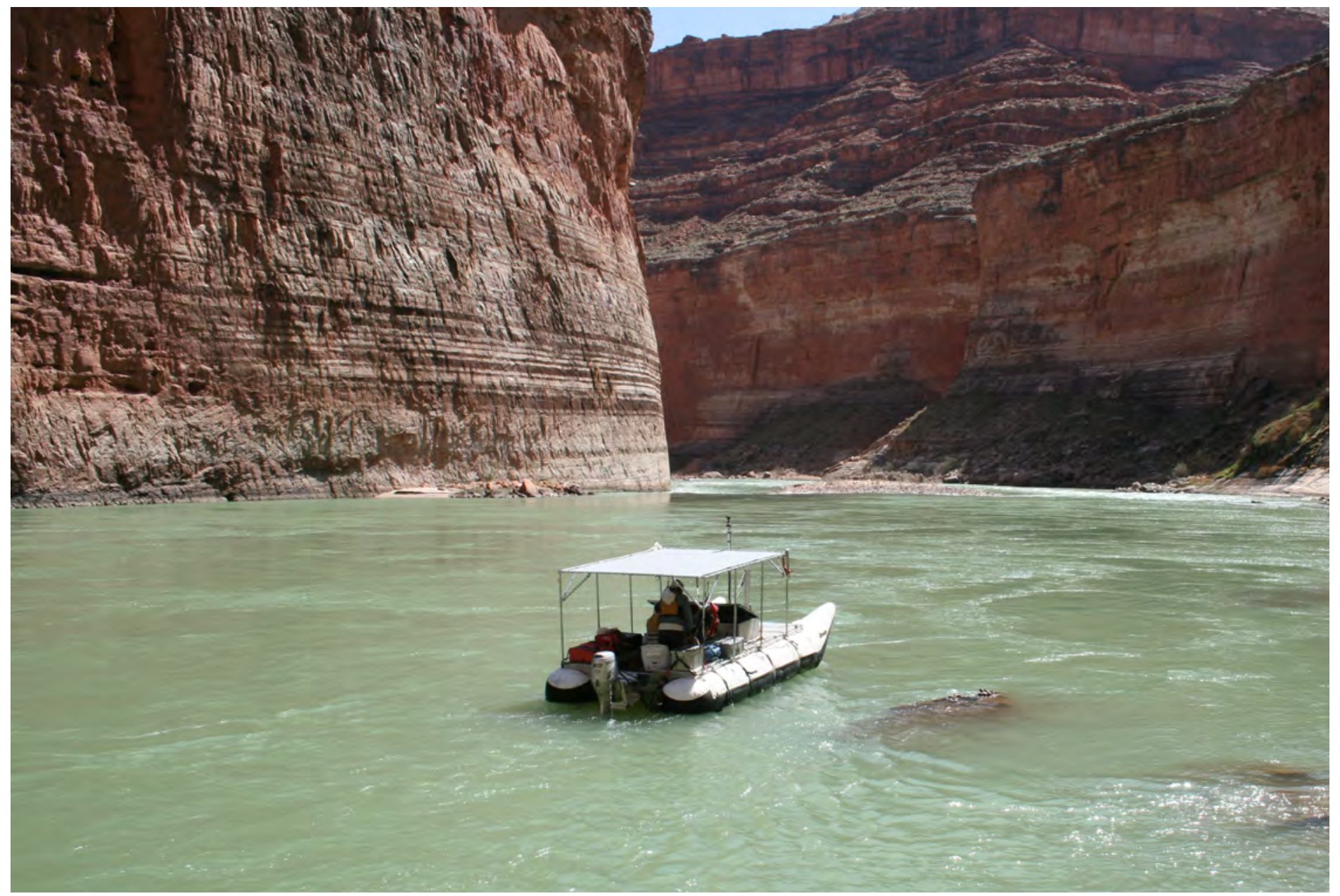

Open-File Report 2009-1207 
Cover: Photograph of multibeam surveying near South Canyon, Grand Canyon National Park. (Photograph courtesy of Joseph E. Hazel, Jr., Northern Arizona University) 


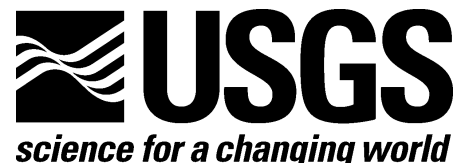

Prepared in cooperation with Northern Arizona University and Utah State University

\section{Monitoring Fine-Sediment Volume in the Colorado River Ecosystem, Arizona: Bathymetric Survey Techniques}

By Matt Kaplinski, Joseph E. Hazel, Jr., Rod Parnell, Mike Breedlove, Keith Kohl, and Mark Gonzales

Open-File Report 2009-1207

U.S. Department of the Interior

U.S. Geological Survey 


\section{U.S. Department of the Interior \\ KEN SALAZAR, Secretary}

\section{U.S. Geological Survey}

Suzette M. Kimball, Acting Director

\section{U.S. Geological Survey, Reston, Virginia 2009}

For product and ordering information:

World Wide Web: http://www.usgs.gov/pubprod

Telephone: 1-888-ASK-USGS

For more information on the USGS - the Federal source for science about the Earth, its natural and living resources, natural hazards, and the environment:

World Wide Web: http://www.usgs.gov

Telephone: 1-888-ASK-USGS

Suggested citation:

Kaplinski, M., Hazel, J.E., Jr., Parnell, R., Breedlove, M., Kohl, K, and Gonzales, M., 2009, Monitoring finesediment volume in the Colorado River ecosystem, Arizona: bathymetric survey techniques: U.S. Geological Survey Open-File Report 2009-1207, 33 p.

Any use of trade, product, or firm names is for descriptive purposes only and does not imply endorsement by the U.S. Government

Although this report is in the public domain, permission must be secured from the individual copyright owners to reproduce any copyrighted material contained within this report. 


\section{Contents}

Abstract

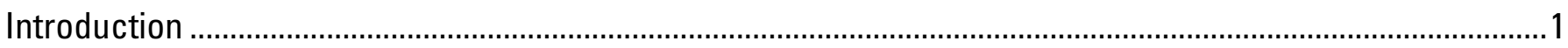

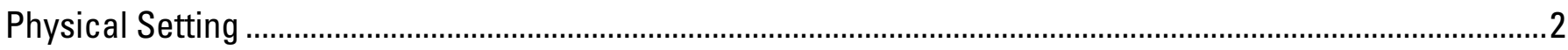

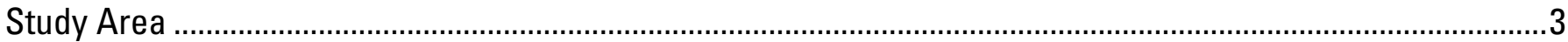

Description of Survey Systems .................................................................................................................

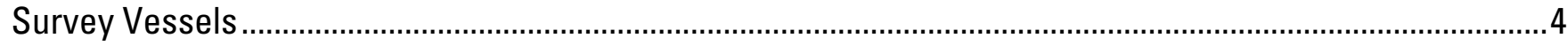

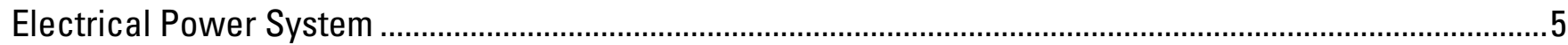

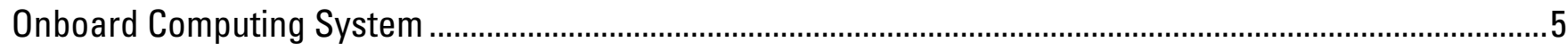

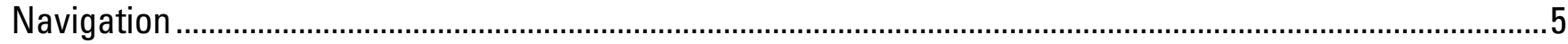

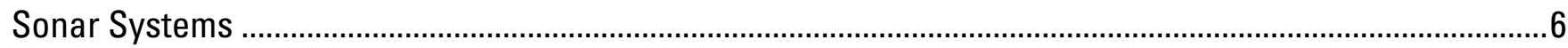

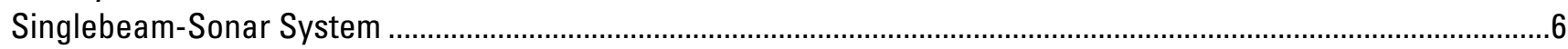

Multibeam-Sonar Systems …………………………………………………………………………………...

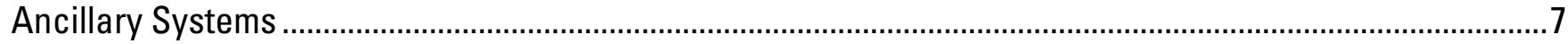

Bathymetric-Data Collection Procedures ………………….......................................................................

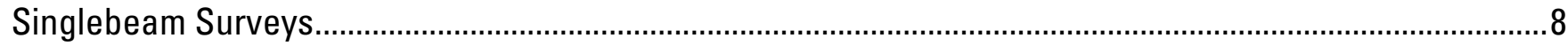

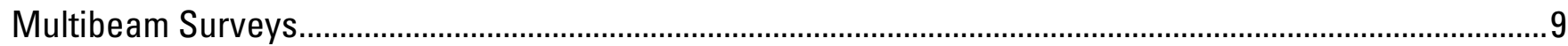

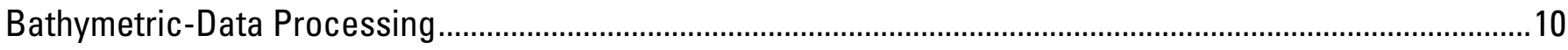

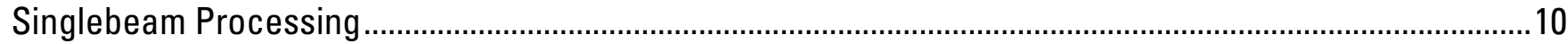

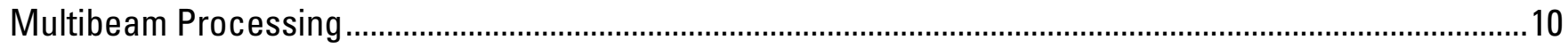

Data Analysis and Measurement Uncertainty ……………………………………………………….....12

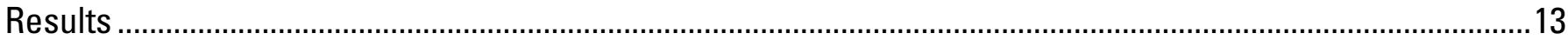

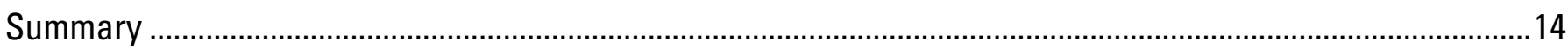

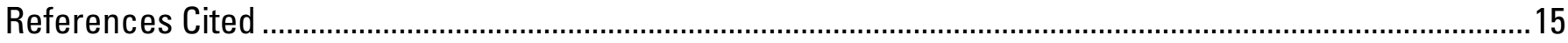

\section{Figures}

1. Map showing the locations of the long-term monitoring reaches in the Colorado River in Grand Canyon National Park, Ariz

2. Discharge hydrograph from U.S. Geological Survey gaging station Colorado River near Lees Ferry (09380000) during the period of study.

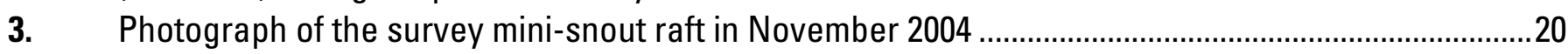

4. Photograph of the Spectra Precision Geodimeter ATS-PT robotically tracking the survey raft.........21

5. May 2002 orthophotography of long-term monitoring reach \#5, Point Hansborough, showing the

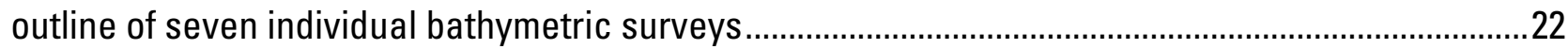

7. Processing flow chart for multibeam bathymetry.................................................................................

8. Screen capture of Phase-1 data processing showing survey tracklines, tide elevations, heave, pitch, and roll data windows...................................................................................................... 25

9. Screen capture of Phase-2 data processing showing cross-section view of the sweep edit window with soundings from a rocky shoreline .........................................................................................26

10. Screen capture of Phase-2 data processing showing cross-section view of the sweep edit window with soundings from a sandy shoreline

11. Screen capture of Phase-3 data processing showing map view and cross-section view of the matrix editor. 
12. Diagram depicting components of cross line check root mean square uncertainty estimation

\section{Tables}

1. Characteristics of the long-term monitoring reaches within the study area, Colorado River, Grand Canyon National Park, Ariz .....

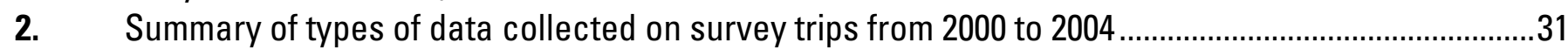

3. Bathymetric survey equipment configuration for each survey trip ....................................................32

4. Summary of estimated depth-uncertainty assessment for each survey trip.

\section{Conversion Factors}

\section{SI to Inch/Pound}

\begin{tabular}{lll}
\hline \multicolumn{1}{c}{ Multiply } & \multicolumn{1}{c}{ By } & \multicolumn{1}{c}{ To obtain } \\
\hline Length & & \\
\hline centimeter $(\mathrm{cm})$ & 0.3937 & inch (in.) \\
meter $(\mathrm{m})$ & 3.281 & foot $(\mathrm{ft})$ \\
kilometer $(\mathrm{km})$ & 0.6214 & mile $(\mathrm{mi})$ \\
\hline Area & & \\
\hline square meter $\left(\mathrm{m}^{2}\right)$ & 0.0002471 & acre \\
\hline Volume & & \\
\hline cubic meter $\left(\mathrm{m}^{3}\right)$ & 35.31 & cubic foot $\left(\mathrm{ft}^{3}\right)$ \\
\hline Mass & & \\
\hline megagram $(\mathrm{Mg})$ & 1.102 & ton, short $(2,000 \mathrm{lb})$ \\
\hline
\end{tabular}

In this report, horizontal and vertical coordinate information is referenced to the North American Datum of 1983 (NAD 83). 


\title{
Monitoring Fine Sediment Volume in the Colorado River Ecosystem, Arizona: Bathymetric Survey Techniques
}

\author{
By Matt Kaplinski ${ }^{1}$, Joseph E. Hazel, Jr. ${ }^{1}$, Rod Parnell', Mike Breedlove ${ }^{2}$, Keith Kohl ${ }^{3}$, and \\ Mark Gonzales
}

\begin{abstract}
In 2002, a fine-grained sediment (sand, silt, and clay) monitoring effort was initiated in the Colorado River ecosystem, the river corridor downstream from Glen Canyon Dam, to directly survey channel topography at scales previously unobtainable in this canyon setting. This report presents an overview of the equipment and the methods used to collect and process the high-resolution bathymetric data required for this monitoring effort. The survey methods were employed in up to 11 discrete reaches during various time intervals. The reaches varied in length from 1.3 to $6.4 \mathrm{~km}$. An assessment of depth-measurement uncertainty is presented that shows the surveys meet or exceed the requirement needed to detect changes at the 0.25 -m level with 95 percent confidence. These data, in the form of high-resolution digital elevation models, will be integrated in a geographic information system and used to compare maps of topography, grain size, and other information to study the spatial distribution of fine sediment in this system.
\end{abstract}

\section{Introduction}

Measurements of topography and bathymetry are integral components of a comprehensive program to monitor changes in fine-grained sediment (sand, silt, and clay) storage in the Colorado River ecosystem (CRE), the river corridor downstream from Glen Canyon Dam. Closure of Glen Canyon Dam in 1963 reduced the fine-sediment supply to the modern river by 95 percent at the upstream boundary of the CRE (Andrews, 1991; Topping and others, 2000). Tributaries now provide the only sediment input to the CRE. Computing fine-sediment budgets for the Colorado River in decadal or longer timescales is required for evaluating the effects of dam operations, including high flows intended to rebuild eroded sand deposits (Wohl and others, 2006). Sand deposits are considered

\footnotetext{
${ }^{1}$ School of Earth Sciences and Environmental Sustainability, Northern Arizona University, Flagstaff, Arizona

${ }^{2}$ Department of Watershed Sciences, Utah State University, Logan, Utah

${ }^{3}$ U.S. Geological Survey, Flagstaff, Arizona

${ }^{4}$ Holman's, Tempe, Arizona
} 
important because they provide substrate for habitat and campsites for recreation (Wright and others, 2005; Kaplinski and others, 2005). Under the prevailing dam-regulated conditions, 90 percent or more of the fine sediment is stored in the channel at elevations that are inundated by dam releases of $227 \mathrm{~m}^{3} / \mathrm{s}$ or less (Hazel and others, 2006). Therefore, measurement of the volume and distribution of fine sediment requires bathymetric mapping. Coarsely spaced cross-sections of channel topography are not adequate to answer questions about the sediment-storage condition of the channel or for tracking the movement of tributary-supplied sediment pulses through the system (Flynn and Hornewer, 2003). Three-dimensional surveys of short segments of the channel $\left(10^{2}-\right.$ $10^{3} \mathrm{~m}$ ) with singlebeam sonar have proved useful for evaluating morphologic changes during short-duration, experimental high-flow releases (Andrews and others, 1999; Hazel and others, 1999; Hazel and others, 2006). However, changes in low-elevation storage computed from repeat bathymetric measurements in short reaches are not consistent with the change in storage computed from longer reaches $\left(10^{4}-10^{5} \mathrm{~m}\right)$ based on measurements of sediment transport (Schmidt, 1999; Topping and others, 2006). Recent developments in multibeam bathymetric mapping make it possible to extend repeat channel monitoring to longer reaches of the channel.

The present study improves the use and data-processing techniques of singlebeam and multibeam mapping to assess sediment storage in the CRE. In an attempt to better study channel change and fine-sediment transport in the CRE, the U.S. Geological Survey (USGS) Grand Canyon Monitoring and Research Center (GCMRC), in cooperation with Northern Arizona University, initiated a channel-mapping project in 2002. This study's technique covers the entire channel at resolutions sufficient to fully represent three-dimensional channel from below the $2,747-\mathrm{m}^{3} / \mathrm{s}$ stage elevation in up to $11 \mathrm{CRE}$ reaches 3-5 km in length (Hazel and others, 2008). The bathymetric data were collected with singlebeam and multibeam (swath) sonar in a range of water discharges. The bathymetric data were then combined with remote-sensing data from airborne laser scanning (LIDAR) and aerial photogrammetry to construct high-resolution digital elevation models (DEMs) of the study reaches (for example, Topping and others, 2006; Kaplinski and others, 2007). In this report, we outline the data collection, processing, and error-analysis procedures used in the bathymetric-mapping component of the channelmapping effort.

\section{Physical Setting}

The Colorado River channel in Grand Canyon is mostly constrained by bedrock, talus, or coarse-grained (sand, gravel, and boulders) debris fans. Width of the channel and of the alluvial valley varies in relation to the erodibility of bedrock that outcrops at river level (Howard and Dolan, 1981). Leopold (1969) described the river as having a longitudinal profile characterized by pools and drops. Magirl and others (2008) used modern remote-sensing techniques to show that 66 percent of the elevation drop in the river occurred in rapids and riffles, which comprise only 9 percent of the distance of the river. The average water-surface gradient is 0.0015 between Lees Ferry and Diamond Creek and ranges from less than 0.0005 in pools to greater than 0.01 in rapids (Schmidt and Graf, 1990). 
Debris fans that occur at the mouth of each steep tributary partially block the Colorado River's course and control the distribution of pools and drops in the river profile. Schmidt and Rubin (1995) termed the length of the mainstem river hydraulically affected by a particular fan the fan-eddy complex. Fan-eddy complexes affect the watersurface slope, water velocity, and depth for as much as several kilometers upstream and downstream from each alluvial fan. Each fan-eddy complex includes a region of ponded flow upstream from the fan where mean velocity is relatively low. Rapids and riffles, where the depths are typically too shallow for multibeam surveys, occur adjacent to the debris fans. A pool or scour-hole exists immediately downstream from rapids and adjacent to large areas of recirculating flow, or eddies (Schmidt and Graf 1990). The scour holes are typically the deepest part of the fan-eddy complex and range in depth from 15 to $28 \mathrm{~m}$. Sandbars, a characteristic feature of the river corridor, are deposited within eddies. Average depths of the surveys range from 3 to $4 \mathrm{~m}$ in wide alluvial reaches and from 7 to $8 \mathrm{~m}$ in narrow reaches.

\section{Study Area}

The study area is the CRE in Glen, Marble, and Grand Canyons, Arizona (fig. 1). The use of the river mile (RM) to measure distances along the Colorado River has a historical precedent. Lees Ferry (RM 0) is the starting point, with distance measured downstream or upstream (negative values) from Lees Ferry. Although we use metric units for describing our methods and results, we adhere to the use of RM and informal names to specify study-site locations. The RM measurements used in this report are defined by the location along the RM centerline developed by the GCMRC (U.S. Geological Survey, 2006).

The 11 reaches selected for repeat monitoring are listed in table 1 . This subset of the channel comprises approximately 10 percent of the CRE between Glen Canyon Dam and Diamond Creek, Arizona. Protocol development was accomplished during June, August, and September 2000 in four of the reaches as part of a separate experiment (Schmidt and others, 2007). The reaches vary from 1.3 to $6.4 \mathrm{~km}$ in length, and the average length is $2.4 \mathrm{~km}$. One reach is located in Glen Canyon, upstream from Lees Ferry. Five reaches are located in Marble Canyon, between Lees Ferry and the confluence with the Little Colorado River (RM 61.7). Two reaches are located in eastern Grand Canyon, between the Little Colorado River and Phantom Ranch (RM 88). Three reaches are located in western Grand Canyon, between Phantom Ranch and Diamond Creek (RM 226). In 2004, emphasis was placed on reaches in Marble Canyon and eastern Grand Canyon. These reaches comprise approximately 18 percent of this portion of the CRE. The reaches located in Glen and western Grand Canyons were only surveyed once in 2002.

Bathymetric data were collected, processed, and analyzed from six river trips conducted in August 2000, September 2000, May 2002, May 2004, November 2004, and December 2004 (fig. 2, table 2). The first two trips included both singlebeam and multibeam surveys. Twenty-six individual surveys (20 multibeam and 6 singlebeam) were conducted in August and September 2000 in reaches 2, 4, 5, and 7. All 11 monitoring reaches were surveyed in May 2002, for a total of 56 surveys. In June 2004, 
logistical and budgetary constraints limited the surveys, and only reaches 2 through 8 were surveyed for a total of 38 surveys. The November and December 2004 surveys were further constrained by shorter daylight hours, and a total of 31 surveys were completed in reaches 2 through 7. In addition to the bathymetric surveys, ground-topographic (Hazel and others, 2008) and grain-size data were also collected, and LIDAR or photogrammetric overflights were conducted during each river trip.

\section{Description of Survey Systems}

Bathymetric data-collection systems are composed of a number of separate sensors and instruments. The primary system components consist of a survey vessel, a sonar system to acquire soundings of the river bottom, a navigation system to accurately plot the location and elevation of the survey vessel, and a number of ancillary systems that include the motion (heave, pitch, and roll) sensor, a gyrocompass, an instrument to measure the speed of sound within the water column, and a computer to store the various datasets. We used a variety of sensor combinations during each of the six data-collection trips outlined in this report (table 3 ).

\section{Survey Vessels}

The survey vessel used during all of the surveys is a 5-m long, 2.6-m wide "minisnout" raft. The mini-snout raft, which is powered by a 50 horsepower outboard motor, uses two 0.71-m-diameter inflatable pontoons and a single-piece aluminum deck/frame (fig. 3). Vessel speed varies from 0.1 to $8 \mathrm{~km} / \mathrm{hr}$ during survey operations, and the twin flotation-tube design provides a stable work platform that minimizes pitch and roll. The vessel is equipped with an aluminum box and decking to accommodate the survey crew and equipment. The aluminum box contains all of the sensitive electronics, and the placement of each component has been designed to minimize the time needed for assembling and disassembling the bathymetry data-collection system. Inside the box are the computer, LCD monitors, sonar processors, motion compensator, gyrocompass, and main power connections. The LCD monitors are mounted with a swivel assembly onto the lid of the box.

The boat is also equipped with a swiveling side-mast assembly. This adjustable mast is designed to house a positioning laser target on top and a submerged transducer on the bottom. With the combination of tube buoyancy and an adjustable transducer draught, the boat can survey in depths as shallow as $0.5 \mathrm{~m}$ when configured for singlebeam surveys. The boat was also fitted with a nylon canopy to shade the surveyors and equipment, reduce heat buildup in the system, and enhance viewing of the computer monitors.

Navigating the rapids of the Colorado River in Grand Canyon requires that the entire system be shock mounted and waterproof. The system is disassembled into travel mode if a rapid or riffle exists between surveys and at the end of the day. In the travel mode, which allows the vessel to travel at speeds up to $35 \mathrm{~km} / \mathrm{hr}$ and move with the current, the system is powered down, monitors are strapped to the inside lid of the box, the navigation target is removed from the mast, and the mast is swiveled to the horizontal position. When in operating mode, the lid is propped open, the monitors are swung down 
for viewing, and the mast assembly is rotated into position with the active target mounted on top of the mast. A series of predrilled holes in the transducer pole shaft are pinned in place to ensure that the entire assembly returns to the same position upon deployment. A side-brace pole was added in 2002 to minimize pole wobble (fig. 3). The entire system can be switched between operating and travel modes within 10 minutes.

During the August and September 2000 survey trips, two mini-snout rafts were used-one configured with a singlebeam system and one with a multibeam system. All other trips used one mini-snout raft configured to collect multibeam data.

\section{Electrical Power System}

The electrical power system was designed specifically to operate in remote and rugged environments. The system is comprised of a generator, batteries, inverter-charger system, and a power-connection box. A submerged ground plate is mounted on the bottom of the transom to ensure a good grounding connection. The ground plate is connected to a large copper welding cable that runs the inside perimeter of the frame so that all electronic devices have easy access to the ground connection. The other end of the ground cable connects directly to the outboard motor to reduce electric noise caused by static build up.

\section{Onboard Computing System}

We used an environmentally sealed, PC-based (Windows 95, Windows XP) computer system for both the singlebeam and multibeam surveys that features o-ring seals on display controls and hinges, shock-mounted electronics, waterproof or splashresistant connectors, noncorrosive impact-resistant plastic cases with stainless steel hardware and one to three sealed $0.38-\mathrm{m}$, backlit flat-panel displays that were easily viewable in direct sunlight. The computer is equipped with eight serial (COM) ports and an ethernet connection to receive input from all survey devices. Both the computer housing and the monitor are equipped with internal cooling fans that direct heat to external heat-sink plates.

The Hypack, Inc., software suite (Hypack and Hysweep) is used to collect, store, and process the bathymetry data. All input devices for the survey are configured and interfaced to the Hypack software. The sonar operator and boatman have a real-time display on the computer monitor of the incoming datasets, including real-time displays of the multibeam coverage to assess any gaps in coverage. Hypack receives the positioning information from the navigation system (described below), and coordinates are displayed in the form of a map with a cursor indicating the boat position and a left-right indicator. With this data displayed, the boatman can precisely maintain the vessel on preestablished survey lines.

\section{Navigation}

We used a range-azimuth navigation system for all of the bathymetric surveys described in this report (fig. 4). Within the deeper, narrower sections of the channel, Global Positioning System (GPS) signals are not reliable because of steep canyon walls, variations in the geometric integrity (PDOP), and multipath errors created by movement 
of the vessel. GPS instruments can be used for hydrographic mapping in wider reaches of the river, such as the Granite Park area (fig. 1). However, a range-azimuth system is preferred for use in Grand Canyon because of its ability to provide highly accurate positioning information in all sections of the river corridor.

The range-azimuth system uses a shore station (robotic total station) located on a monumented river-corridor control-point benchmark to track the position and elevation of a target mounted on the survey vessel. The raw positioning information (slope distance, horizontal and vertical angles) is referenced to the benchmark and transmitted back to the vessel by radio modems 4 times per second, or $4 \mathrm{~Hz}$. The measured depths are then subtracted from the elevation of the transducer to derive bottom elevations. Using elevations, rather than depths, eliminates the need for independent measurements of water level (tides), a major source of uncertainty in hydrographic surveying (Byrnes and others, 2002). We used a Geodimeter ATS-PT from Spectra Precision as the shore station to track the survey vessel. As estimated by the manufacturer, the Geodimeter ATS-PT provides measurement accuracies of $\pm 10 \mathrm{~mm}$ in distance and 1-second angle measurement.

Range-azimuth surveys require benchmarks that provide an unobstructed view of the survey area. Temporary benchmarks determined by conventional total station surveying were utilized in areas where control points did not exist or the benchmark did not provide sufficient line of sight (Hazel and others, 2008). Control points in the network are referenced to the NAD83 datum in Arizona Coordinate System, Central Zone grid in meters. Hazel and others (2008) report horizontal and vertical accuracies of the river-corridor control points as $0.05 \mathrm{~m}$ and $0.08 \mathrm{~m}$, respectively. Benchmark and backsight coordinate values were verified in the field using multiple angles in both direct and reverse scope and by multiple distance measurements and yielded an average positional error of $0.011 \mathrm{~m}$ horizontally and $0.006 \mathrm{~m}$ vertically (Hazel and others, 2008).

\section{Sonar Systems}

\section{Singlebeam-Sonar System}

During the August and September 2000 survey trips, we deployed two bathymetric-survey systems - one singlebeam system and one multibeam system. An Innerspace model 448 echosounder measured water depths using a narrow beam (2degree) transducer operating at $200 \mathrm{kHz}$. Manufacturer specifications for this depth sounder report that the depth of operation is from 0 to $100 \mathrm{~m}$, with a sounding rate of 20 $\mathrm{Hz}$ and the depth-measurement accuracy is $\pm 0.03 \mathrm{~m}$. Digital depths were transmitted to the data-collection computer using a RS232 serial connection.

\section{Multibeam-Sonar Systems}

We used a Reson SeaBat 8124 multibeam-sonar system during the August and September 2000 surveys in conjunction with a singlebeam system. The 8124 multibeam echosounder system is a $200 \mathrm{kHz}, 120$-degree-swath echosounder specifically designed for shallow surveys. The swath width is proportional to water depth by a ratio of 3.5:1. The system was upgraded to 80 beams with a 1.5 by 1.5 -degree beamwidth. The system 
has a range resolution of $0.01 \mathrm{~m}$, an update rate of up to $30 \mathrm{~Hz}$, and includes both phase and amplitude detection of the incoming transducer signal.

During the 2002 and 2004 surveys we used a Reson SeaBat 8125 ultra highresolution echosounder system. The Seabat 8125 system provides the same swath width (120 degrees) as the 8124 , but has a much higher resolution. With a $455 \mathrm{kHz}$ frequency ( 240 beam, 1 by 0.5 -degree beamwidth), the SeaBat 8125 has a depth resolution of 0.006 $\mathrm{m}$, with an update rate of up to $40 \mathrm{~Hz}$.

\section{Ancillary Systems}

Multibeam-sonar measurements require an accurate measure of the vessel motion during operation. We used a TSS DMS (Dynamic Motion Sensor)-05 and a TSS MAHRS (Meridian Attitude and Heading Reference System) to provide heave, pitch, and roll correction to the singlebeam and multibeam data. The TSS DMS-05 was used in the August 2000, September 2000, and May 2002 surveys. In 2004, we upgraded the motion sensor to the MAHRS unit. The DMS-05 measures the vessel motion (pitch, roll, and heave) at $100 \mathrm{~Hz}$, with an accuracy of 0.04 degrees for pitch and roll and $0.05 \mathrm{~m}$ or 5 percent of heave amplitude, whichever is greater. The MAHRS system is a combined motion sensor and gyrocompass unit that provides an accuracy of 0.03 degrees of pitch and roll measurement at a rate of $50 \mathrm{~Hz}$ and $0.05 \mathrm{~m}$ or 5 percent of heave amplitude, whichever is greater. All of these sensors were interfaced to the data-collection computer through Hypack software with an RS232 serial connection.

Multibeam-sonar systems measure depth in a swath perpendicular to the sonar transducer. It is, therefore, necessary to know the precise heading, or yaw, of the survey vessel in order to accurately locate each sounding. Three different compasses were used during the multibeam surveys to measure the vessel yaw. The singlebeam systems were not equipped with a compass, as they do not require yaw corrections to correctly align the soundings. A KVH Azimuth Digital Gyrocompass (ADGC) was used for yaw corrections during the August and September 2000 multibeam surveys. The KVH ADGC is a fluxgate compass that measures the angle of the vessel with a resolution of 0.1 degrees and an accuracy of 1 degree and a maximum angular velocity of 45 degrees per second and an update rate of $10 \mathrm{~Hz}$. The fluxgate compass is affected by local magnetic attractions on and around the vessel. These local magnetic attractions are compensated for during routine calibration procedures. In 2002, we used a KVH GyroTrac compass for yaw measurements. The Gyrotrac provides the same specifications as the ADGC, but it is not sensitive to magnetic fluctuations and is considered a better system for our application. Both the ADGC and Gyrotrac compasses require that calibration procedure be completed before surveying can begin. In 2004, we upgraded the yaw measurement system by using the new TSS MAHRS system. Heading information from the MAHRS unit provides a dynamic accuracy of 0.1 degrees and maximum angular velocity of 200 degrees per second and an update rate of $50 \mathrm{~Hz}$. With improved accuracies over previous sensors, the MAHRS unit also combines a motion sensor and gyrocompass in one unit. The improved accuracy and ability to provide stable heading information during high-rate turns is especially important in our application, which demands frequent high-rate turns to stay online within a variety of flow conditions. 
Because sonar depth measurements are based on a time-distance relationship, the speed of sound in the water column must be accurately measured. An Odom Digibar Pro velocity meter was used during the multibeam surveys to determine the sound velocity. The Digibar Pro velocimeter employs the sing-around method to measure the sound velocity with an accuracy of $0.3 \mathrm{~m} / \mathrm{s}$ and samples at a rate of $10 \mathrm{~Hz}$. Sound-velocity profiles collected show that the water column is well mixed. Five sound-velocity profiles were collected at the same time across the channel (one profile near each side of the river and three in the middle of the channel), and the combined measurements from all profiles across all depths show a standard deviation of $0.1 \mathrm{~m} / \mathrm{s}$. Therefore, we collected a single velocity cast each day to determine the speed of sound in the water column.

\section{Bathymetric-Data Collection Procedures}

Bathymetric survey extent is constrained by rapids and also by the line-of-sight range azimuth-navigation system, which has a maximum range of 1,200 $\mathrm{m}$. Because of local viewscape considerations and data degradation at longer ranges, we limited the range of operations to within $600 \mathrm{~m}$ of the shore station. Within each study reach, four to seven individual shore-station positions were required to survey the entire reach. Data collected from each shore station position is considered an individual survey and each survey is collected and processed separately (fig. 5).

Shore station control-point verification is the same for singlebeam and multibeam surveys. Once the shore station is leveled over an existing control point, the geodimeter ATS-PT horizontal angle is set to zero on a backsight located at another control point. The coordinates of the shore station ( $x, y$, and $z+$ instrument height) and azimuth from the benchmark to the backsight are entered into the Hypack hardware setup program. The horizontal, vertical, and slope distance to the backsight is measured by the geodimeter and noted to verify the position. Following the backsight observation, the geodimeter sight is trained on the vessel target and a series of commands initiates the radio link to transfer control of the instrument to the vessel computer. Once the incoming geodimeter transmission is verified by the surveyor, the vessel position is checked by noting the placement of the vessel cursor within the Hypack-survey map screen that has referencing files (typically an orthophoto of the area), control points, and preset transect lines displayed. The vessel also conducts a pre-survey transect to verify that the geodimeter coordinates place the vessel in the correct coordinate space.

The accurate reduction of bathymetric data critically depends on accurately measuring the geometry and relative positions of the sonar transducer relative to the survey vessel, motion and heading sensors, and the position of the navigation target. We used standard survey techniques before each trip to measure these values.

\section{Singlebeam Surveys}

During the August and September 2000 trips we conducted singlebeam surveys at one or two sites per day. Before, during, and after each trip, the echosounder was calibrated using the barcheck procedure. The barcheck consists of lowering an acoustic target (a 0.46-m-diameter circular metal plate) using a measured cable below the 
transducer and calibrating the observed depths with the known target depth (U.S. Army Corps of Engineers, 2002).

Singlebeam surveys were collected along a 10 by $10 \mathrm{~m}$ transect grid within the surveyed area. The transect lines are preplanned and displayed in the Hypack survey program, and the bathymetric data are collected along each of the lines individually. Once a line is selected, the boatman navigates the vessel along the line until completed. The boatman is aided in navigation along the selected line by information displayed on the computer screen. The Hypack data-collection screen displays a map image of the survey area as well as a left-right indicator showing how far left or right the boat is located from the selected transect line. All of the survey information is time tagged and stored on the computer through the Hypack survey software. Backups of the data files are made following each survey.

\section{Multibeam Surveys}

In addition to careful measurements of transducer alignments and systemcomponent offsets, the geometry of the installed systems for multibeam surveys is determined by a series of calibration routines collectively known as a patch test (U.S. Army Corps of Engineers, 2002). The patch test determines correction factors for mounting angles of the various system components and positioning latency by analyzing data collected along a series of preplanned lines. Several patch tests were conducted before each multibeam-survey trip. Patch test lines were also collected during the trips in case any of the system components were moved from their original positions. Following data collection, the patch-test program in Hypack was used to calculate the roll, pitch, and yaw mounting angles corrections plus the positioning-system latency. These angular offsets are entered into the Hypack software and applied to all of the data.

Before beginning a multibeam survey all system components are calibrated and checked for proper operation. In the 2000 and 2002 surveys, the ADGC and Gyrotrac compasses required a calibration procedure before operation, which was completed at the start of each day. The MAHRS unit has a selfcalibration routine that runs on power up, which can take up to 30 minutes to complete. This procedure was conducted upon power up each day.

Multibeam surveying also follows preplanned survey lines. However, preplanned survey lines, constructed from orthophotography, do not always take into account the variable current lines and eddy fences. Therefore, it is often necessary to establish lines while onsite to incorporate the local current velocity fields, which makes navigating each survey line easier.

Once the line files are established, each line is followed and the data collected. The Hypack program displays a grid of the survey area where the individual grids are color coded by depth as soundings are collected. This allows the survey crew to observe the survey coverage as it is collected. Following collection along the line files, open areas within survey grid, or areas not covered by running the lines are run to ensure swath overlap (fig. 6).

During the June, November, and December 2004 surveys, we rotated the Reson 8125 sonar head 30 degrees to starboard to extend the swaths further towards shoreline 
areas. Tilting the transducer increased our efficiency by reducing the number of line files needed to completely cover the survey site and minimized the risk of impacting the sonar head on submerged rocks near the shoreline.

\section{Bathymetric-Data Processing}

We used the Hypack suite of software tools to process and output all of the bathymetric data collected in this study. In general, processing involves deleting spikes or errors from the navigation, heave, pitch, roll, and sounding data. The processing procedures are different for each system, with the multibeam procedures being more labor intensive and time consuming.

\section{Singlebeam Processing}

Singlebeam processing follows a three-phase editing process. We used the Hypack Inc., singlebeam editor SBMax for all singlebeam processing. Phase 1 editing primarily involves editing spikes in the navigation data, which is shown in map form in a window. In Phase 2 of the editing, the depth and positioning information are integrated and erroneous soundings, indicated by spikes in the bottom trace, are deleted. Once the positioning and depths are edited, the singlebeam line files are filtered to include only one depth every $1 \mathrm{~m}$ in horizontal distance. The output is an ASCII-coded text file that includes the XYZ coordinates for each line surveyed. These files are then merged into one file that contains all of the points for each survey.

\section{Multibeam Processing}

We followed a five-phase procedure for editing the multibeam data (fig. 7). Phase 1 editing involves opening each line file of a survey in the Hypack MBmax multibeamprocessing module and deleting erroneous points from the vessel tracklines, navigation target elevations, heave, pitch, and roll data. Each data item is displayed separately in a window, where a number of tools are available to detect and delete erroneous data (fig. 8). The Hypack software team developed a special module for editing soundings in elevations, rather than depths, by inputting the elevation of the navigation target as a tide file. The tide, heave, pitch, and roll files are displayed as graphs versus time of collection in separate windows, and the vessel navigation is displayed in a map for each line selected. Phase 1 is completed when the erroneous data, typically navigation and tide deviations, are removed from each line file from a particular survey.

In phase 2, or sweep editing, raw soundings from each line file are edited. This is accomplished by a series of automated filters and by manual inspection. An initial filter pass is run on all of the lines within a survey. The initial filtering typically includes deleting points above the elevation of the water surface at the time of the survey and below the minimum pool elevation. The Reson sonar processor assigns each sounding with a quality indicator that ranks the soundings in four classes (low to high quality). We use an automated filter to delete the two lowest classes. During the August and September 2000 surveys, the Reson processing software incorrectly assigned the quality indicators, so the filter was not used for these surveys. Other filters are applied on a line- 
by-line basis. These filters include a spike filter (user-defined elevation changes from one sounding to the next within a sweep), an undercut topography filter, elevation limits (other than the water level and minimum pool elevation). These filters are applied sparingly and only in specific areas of individual lines. Soundings identified by the filters are inspected before deleting the points to ensure the automated procedure is not deleting good soundings. During the May, November, and December 2004 surveys, we rotated the transducer 30 degrees to starboard, which resulted in sweep angles of 30 degrees to port and 90 degrees to starboard. These surveys were filtered to accept only soundings from beam angles of 70 degrees or less. Soundings from beam angles greater than about 70 degrees were found to be extremely noisy. Sweep editing is the most time consuming and tedious phase of the editing process. Once the line files are run through the initial filters, soundings from each survey line are manually inspected and bad points are deleted. Each individual line file consists of several thousand to several hundred thousand individual sweeps that require visual inspection. Regardless of file size, each sweep contained a significant amount of noise-even after initial filtering. The noise is thought to be due to the acoustic environment of the Colorado River, side-lobe interference (at low transmit power settings), and, to a lesser extent, improper sonar-processor settings during collection. Rapid changes in topography, aeration, and substrate necessitated frequent adjustment of the range, gain, and power settings in order to maintain a good bottom signal. The result of operating in this environment was a noisy dataset, which in turn made the sweep editing process difficult. The cross sections in figures 9 and 10 show 30 sweeps collected along a typical shoreline area. Individual soundings are displayed as colored dots, and the color range indicates depth. Assuming a vessel speed of $1 \mathrm{~m} / \mathrm{s}$, each 30 -sweep view shows approximately $1 \mathrm{~m}$ of along-track coverage. Points that were deemed unacceptable are shown with a red "x" plotted on top of the dot. Sweeps collected along the shallow (1 to $3 \mathrm{~m}$ deep), rocky shorelines were a challenge to edit (fig. 9). Editing of sweep in shallow, sandy areas was more straightforward because bad soundings are more easily recognized (fig. 10). We edited conservatively and deleted soundings where it was not possible to clearly distinguish between noise and true bottom soundings, which occurred most frequently in nearshore areas. Each survey contained approximately 10 to 40 separate line files and required 8 to 16 person hours to complete the sweep editing process.

Phase 3 of the editing begins by placing all the individual sweep soundings in a grid or matrix. During this step all offset, motion-compensation, beam-steering, and sound-velocity corrections are applied to correctly determine the position and elevation of each sounding. Phase 3 grid editing displays the entire survey in a map window, a cross-section display, and a display showing individual grid cells (fig. 11). Each grid cell is color coded to the median elevation within each grid cell. Grid cells contain all of the soundings within the cell and can contain several hundred points per cell. We chose a 0.25-m grid-cell size for most of the data. However, the August and September 2000 surveys did not contain a sufficient number of points for this grid size, and 0.5-m grid spacing was used. The cross-section view displays all of the soundings that passed sweep editing. Within the map and cross-section views, the user is able to color code the data based on elevation, or individual line files. Until this step, all of the data were treated individually within line files. A number of editing tools are available that allow the user 
to manually or automatically identify and delete soundings within the grid, if necessary. Particular care is taken with points located near the shoreline, where confidence in the sweep editing is lowest. The process involves paging through all of the grid cells and deleting bad soundings. If more than one person is involved in the processing path (Phases 1 to 3), we did not consider the phase complete until another technician inspected the survey. This quality-control step was instituted because of the tedious nature of the editing during Phases 2 and 3, which can lead to errors and oversights by the technician.

Phase 4 of the processing flow involves exporting an ASCII text file of the grid $\mathrm{XYZ}$ values, once the grid editing (Phase 3) is satisfactorily completed. We chose to export the median value of the range in elevations within a cell along with the northing and easting of the $0.25-\mathrm{m}$ grid cell.

Coordinates of the survey control-network benchmarks used in this project were adjusted throughout the study period. Several errors (for example, incorrect shore-station instrument height, translated coordinate numbers, or other inconsistencies) were also identified and corrected. These situations required that the entire bathymetric survey be rotated and translated based on the control-point adjustments. Hypack includes a software module that accomplishes this task. Upon generation of the XYZ files, the gridded data were checked against orthophotography for positioning errors and, where available, ground-truth points were collected by optical total stations to ensure the correct elevations. Further checks occurred during analysis of change between surveys, when areas that should not have changed (gravel bars, talus, bedrock substrates) showed large vertical change. Investigation into the cause of the change subsequently revealed an error (typically incorrect station elevation), which was then rectified.

\section{Data Analysis and Measurement Uncertainty}

When comparing two bathymetric-survey datasets to determine changes in bed elevation, it is critical to assess the measurement uncertainties of each surface in order to understand the significance of the results. Assessing measurement uncertainty is inherently more difficult in bathymetric surveys because of the lack of direct verification of depth observations. Therefore, bathymetric-survey uncertainty can only be approximated through statistical estimation (Byrnes and others, 2002).

We quantified the depth-measurement uncertainty of each survey trip by conducting cross-line checks. A cross-line check compares different datasets, or survey lines, conducted over the same area. Four cross-line checks were conducted for each survey trip. Cross-line checks were conducted on separate surveys during each trip. For each cross-line check 0.25 -m (2002 and 2004 surveys) or 0.5-m (2000 surveys) surface grids were generated for each pair of lines. The difference in surface elevation $(\Delta E H)$ was calculated for overlapping grid nodes within the cross-line area. The data from all four cross-line checks were combined for each survey trip and analyzed statistically to derive an estimate of measurement uncertainty.

Measurement-uncertainty estimates are reported in terms of root mean square uncertainty $(R M S U z)$ at the 95 percent confidence level and the mean absolute uncertainty $(M A U z)$. The concepts used to derive the $R M S U z$ estimates are shown in the depth-dispersion curves in figure 12. The RMSUz combines the precision, or repeatability 
of the observations, plus any systematic biases that may be present in the data. The standard deviation $\left(S D E z=\left[\left(1 /(n-1) \Sigma[\Delta E H i-M E z]^{2}\right]^{1 / 2}\right)\right.$ of the cross-line $\Delta E H$ population or spread of the depth uncertainty is used to indicate precision. Systematic biases are indicated by the mean $(M E z=\Sigma \Delta E H i / n)$ of the cross-line $\Delta E H$ population. The difference of the mean from the "true" depth indicates uncertainty in the depth observations that was not accounted for by system calibration. In this case the "true" value is not known, and the accuracy of the depth observations is estimated by comparing depths observed over the same point on the bottom (that is, $\triangle E H$ deviation from 0 ). Therefore, $R M S U z$ at the 95 percent confidence level is defined using the following expression:

$$
R M S U z=1.96 *\left[(M E z)^{2}+(S D E z)^{2}\right]^{1 / 2}
$$

Because the spread of depth uncertainty follows that of a Gaussian curve, positive and negative uncertainties in determining volume changes between surveys will cancel. Therefore, the $M A U z$ is reported as the uncertainty in determining volume changes between surveys. This is defined as the mean of the absolute value of the $\Delta E H$ population $(M A U z=\Sigma|\triangle E H i| / n)$.

\section{Results}

We have completed the collection, processing, and uncertainty analysis of more than 200 bathymetric surveys in the CRE. The surveys were collected on six separate river trips in August 2000, September 2000, May 2002, June 2004, November 2004, and December 2004. The surveys will be used to understand the effects of Glen Canyon Dam operations on the transport and storage of fine sediment (for example, Topping and others, 2006).

We used a five-phase process to edit the data. During this process, erroneous points are edited from the navigation ( $\mathrm{X}$ and $\mathrm{Y}$ positions and elevations), attitude data (heave, pitch, and roll), and depth soundings. The editing process produces a $0.25-\mathrm{m}$ or $0.5-\mathrm{m}$ grid of points that are used in a GIS analysis of sediment changes within the study reaches. The data are presented as ASCII-coded text files that contain the gridded points of each individual survey.

We estimated the uncertainty of the depth measurements for each survey trip by using a cross-line analysis approach (U.S. Army Corps of Engineers, 2002). The estimated depth uncertainty and volumetric precision are reported as both $M A U z$ and $R M S U z$ (table 4). RMSUz errors ranged from 0.094 to $0.20 \mathrm{~m}$, and $M A U z$ errors ranged from 0.038 to $0.082 \mathrm{~m}$. The highest level of uncertainty was calculated for the August and September 2000 surveys and the lowest uncertainties were associated with the 2004 surveys. These uncertainty estimates have a high degree of confidence because of the large volume of cross-line checkpoints generated with the $0.25-\mathrm{m}$ and $0.5-\mathrm{m}$ bathymetry

grids. The $M E z$ values calculated for each survey trip range between 0.047 and $0.0002 \mathrm{~m}$ and indicate that quality-control and calibration procedures successfully minimized bias in the surveys. 
The goal of the long-term channel monitoring effort is to detect channel-bed changes of $0.25 \mathrm{~m}$ or greater. Topographic surfaces are constructed by combining the bathymetric data described in this study with subaerial LIDAR and/or photogrammetric topographic data into a continuous surface. In order to detect changes at the $0.25-\mathrm{m}$ level with 95 percent confidence, a vertical $M A U z$ uncertainty of $0.09 \mathrm{~m}$ is required (Brock and others, 2001). All of the MAUz estimated depth-error values derived in this study exceed this requirement. The results of the change-detection analysis have been preliminarily discussed by Topping and others (2006).

\section{Summary}

The bathymetric-mapping methods described in this report offer a technique for collecting repeat measurements along kilometer-scale lengths of the channel in a river characterized by complex channel morphology. We developed a bathymetric-survey system that can quickly be deployed from an operational mode to completely waterproof for navigating rapids between sites. The vessel is relatively small $(5 \mathrm{~m})$ and can easily navigate into and around nearshore areas such as backwaters and rocky shorelines. The survey system incorporates a waterproof box to house sensitive electronic components, a rotating mast/transducer assembly, onboard electrical system, data-collection computer, range-azimuth navigation system, motion (heave, pitch, and roll) compensator, and gyrocompass components.

The primary goal of this study was to determine if repeat bathymetry can detect a geomorphically significant level of change, which we defined as $0.25 \mathrm{~m}$. In order to provide a 95 percent confidence level of this level of vertical change, individual topographic surfaces required a $M A U z$ uncertainty level of near $0.09 \mathrm{~m}$. Soundings were edited and reduced to either a $0.5-\mathrm{m}$ or $0.25-\mathrm{m}$ grid of points, depending on the density of the soundings. Cross-line analysis was used to quantify the estimated uncertainty of the surveys. Four cross-line checks totaling more than 15,000 individual point comparisons per survey trip were used to produce an estimated uncertainty for each survey trip. $R M S U z$ uncertainty ranged from $0.094 \mathrm{~m}$ to $0.20 \mathrm{~m}$, and $M A U z$ errors ranged from 0.038 to $0.082 \mathrm{~m}$. Thus, the surveys meet or exceed the requirement needed to detect changes at the $0.25 \mathrm{~m}$ level with 95 percent confidence. These results indicate that the repeat bathymetric surveys collected during this study are of sufficient accuracy to detect potentially small changes in fine-sediment volume and can be confidently combined with other remotely sensed datasets at the reach scale $\left(10^{2}-10^{3} \mathrm{~m}\right)$.

Although the bathymetric data collected provides high-resolution ( $0.25-\mathrm{m}$ grids), there is a need for greater resolution of the channel-bed grain-size distribution. Topping and others (2005) demonstrated that the surface grain size is the dominant regulator of sand transport within multiyear timescales. Therefore, a map of the grain-size distribution, in particular sand-sized sediment, would enhance our interpretation of channel-bed change. While we have approached the limits of multibeam-survey resolution, side-scan sonar and/or multibeam backscatter could possibly distinguish sand, silt, and clay from cobble in this complex riverine environment.

The technology of multibeam bathymetric-data collection and processing advanced rapidly during the course of this study. A major focus of research has been the 
application of automated processing techniques and uncertainty estimation (Calder and Mayer, 2003). These methods were not used because the processing scheme described above was developed before the automated techniques were standardized. However, future surveys will include these advances as they can significantly decrease the amount of processing time and enhance our understanding of the uncertainties associated with the surveys.

\section{References Cited}

Andrews, E.D., 1991, Sediment transport in the Colorado River Basin, in Colorado River Ecology and Dam Management, in Marzolf, G.R., ed., Colorado River ecology and dam management: Washington D.C., National Academic Press, p. 54-74.

Andrews, E.D., Johnson, C.E., Schmidt, J.C., and Gonzales, M., 1999, in Webb, R.H., Schmidt, J.C., Marzolf, G.R., and Valdez, R.A., eds., The controlled flood in Grand Canyon: American Geophysical Union Geophysical Monograph Series 110, p. 117130.

Brock, J.C., Sallenger, A.H., Krabill, W.B., Swift, R.N., and Wright, C.W., 2001, Recognition of fiducial surfaces in lidar surveys of coastal topography: Photogrammetric Engineering and Remote Sensing, v. 67, p. 1245-1258.

Byrnes, M.R., Baker, J.L., and Li, F., 2002, Quantifying potential measurement errors associated with bathymetric change analysis: U.S. Army Corps of Engineers Research and Development Center, Vicksburg, Miss., 17 p.

[http://chl.erdc.usace.army.mil/library/publications/chetn/pdf/chetn-iv-50.pdf, last accessed January 5, 2009].

Calder, B.R., and Mayer, L.A., 2003, Automated processing of high-rate, high-density multibeam echosounder data: Geochemistry Geophysics Geosystems, v. 4, no. 6, 1048.

Flynn, M.E., and Hornewer, N.J., 2003, Variations in sand storage measured at monumented cross sections in the Colorado River between Glen Canyon Dam and Lava Falls Rapid, Northern Arizona, 1992-1999: U.S. Geological Survey Open-File Report 2003-4104, 39 p.

Hazel, J., Jr., Topping, D.J., Schmidt, J.C., and Kaplinski, M., 2006, Influence of a dam on fine sediment storage in a canyon river: Journal of Geophysical Research, v. 111, 16 p.

Hazel, J.E., Jr., Kaplinski, M., Parnell, R., M. Manone, and Dale, A., 1999, Topographic and bathymetric changes at thirty-three long-term study sites, in Webb, R.H., Schmidt, J.C., Marzolf, G.R., and Valdez, R.A., eds., The controlled flood in Grand Canyon, American Geophysical Union Monograph Series, v. 110, p. 161-184.

Hazel J.E., Jr., Kaplinski, M., Parnell, R., Kohl, K., and Schmidt, J.C., 2008, Monitoring fine-grained sediment in the Colorado River Ecosystem, Arizona-control network and conventional survey techniques: U.S. Geological Survey Open-File Report 2008-1276, $15 \mathrm{p}$.

Herzog, J., Snider, F.L, Bradshaw, A.S., 2005, A method for comparing bathymetric survey data to determine changes in sediment elevation: The Hydrographic Journal, no. 118. P. 3-9. 
Hicks, D.M., and Hume, T.M., 1997, Determining sand volumes and bathymetric change on an ebb-tidal delta; Journal of Coastal Research, v. 13, no. 2, p. 407-416.

Howard, A., and Dolan, R., 1981, Geomorphology of the Colorado River in Grand Canyon, Journal of Geology, v. 89, p. 269-298.

Kaplinski, M., Behan, J., Hazel, J., Parnell, R.A., and Fairley, H.C., 2005, Recreational values and campsites in the Colorado River ecosystem, in Gloss, S.P., Lovich, J.E., and Melis, T.S., eds., The state of the Colorado River ecosystem in Grand Canyon: U.S. Geological Survey Circular 1282, p. 193-205.

Kaplinski, M., Hazel, J.E., Jr., Parnell, R., Breedlove, M., and Schmidt, J.C., 2007, Integrating topographic, bathymetric, and LIDAR surveys of the Colorado River in Grand Canyon to assess the effects of a flow experiment from Glen Canyon Dam on the Colorado River ecosystem: Proceedings of the Hydrographic Society of America 2007 Annual Meeting, May 14-17, Norfolk, Va., 22 p.

Leopold, L.B., 1969, The rapids and the pools-Grand Canyon, in the Colorado River Region and John Wesley Powell, U.S. Geological Survey Professional Paper 669, 131 p.

Magirl, C.S., Breedlove, M.J., Webb, R.H., Griffiths, P.G., 2008, Modeling water-surface elevations and virtual shorelines for the Colorado River in Grand Canyon, Arizona: U.S. Geological Survey Scientific Investigations Report 2008-5075, 32 p.

Rubin, D.M., Chezar, H., Harney, J.N., Topping, D.J., Melis, T.S., and Sherwood, C.R., 2006, Underwater microscope for measuring spatial and temporal changes in bedsediment grain size: U.S. Geological Survey Open-File Report 2006-1360, 15 p.

Rubin, D.M., Topping, D.J., Schmidt, J.C., Hazel, J., Kaplinski, M., and Melis, T.S., 2002, Recent sediment studies refute Glen Canyon dam hypothesis: EOS, Transactions, Ameri- can Geophysical Union, v. 83, no. 25, p. 273, 277-278.

Schmidt, J.C., 1999, Summary and synthesis of geomorphic studies conducted during the 1996 controlled flood in Grand Canyon, in Webb, R.H., Schmidt, J.C., Marzolf, G.R., and Valdez, R.A., eds., The controlled flood in Grand Canyon: Washington, D.C., American Geophysical Union, Geophysical Monograph Series, v. 110, p. 329-341.

Schmidt, J.C., and Graf, J. B., 1990, Aggradation and degradation of alluvial sand deposits, 1965 to 1986, Colorado River, Grand Canyon National Park, Arizona: U.S. Geological Survey Professional Paper 1493, 74 p.

Schmidt, J.C., and Rubin, D.M., 1995, Regulated streamflow, fine-grained deposits, and effective discharge in canyons with abundant debris fans, in Costa, J.E., Miller, A.J., Potter, K.W., and Wilcock, P.R., eds., Natural and anthropogenic influences in fluvial geomorphology: Washington, D.C., American Geophysical Union, Geophysical Monograph Series, v. 89, p. 177-194.

Schmidt, J.C., Topping, D.J., Grams, P.E., and Hazel, J.E., Jr., 2004, System-wide changes in the distribution of fine sediment in the Colorado River corridor between Glen Canyon Dam and Bright Angel Creek, Arizona: Grand Canyon Monitoring and Research Center final report [http://www.gcmrc. gov/library/reports/physical/Fine_Sed/ Schmidt2004.pdf].

Schmidt, J.C., Topping, D.J., Rubin, D.M., Hazel, J.E., Jr., Kaplinski, M., Wiele, S.M., and Goeking, S.A., 2007, Streamflow and sediment data collected to determine the effects of low summer steady flows and habitat maintenance flows in 2000 on the 
Colorado River between Lees Ferry and Bright Angel Creek, Arizona: U.S. Geological Survey Open-File Report 2007-1268, 79 p.

Topping, D.J., Rubin, D.M., Nelson, J.M., Kinzel, P.J., III, and Corson, I.C., 2000, Colorado River sediment transport: pt 1: natural sediment supply limitation and the influence of Glen Canyon Dam: Water Resources Research, v. 36, p. 515-542.

Topping, D.J., Rubin, D.M., Schmidt, J.C., Hazel, J.E., Jr., Melis, T.S., Wright, S.A., Kaplinski, M., Draut, A.E., and Breedlove, M.J., 2006, Comparison of sedimenttransport and bar-response results from the 1996 and 2004 controlled-flood experiments on the Colorado River in Grand Canyon, in Federal Inter- Agency Sedimentation Conference, 8th, Reno, Nevada, 2006, CD-ROM Proceedings (ISBN 09779007-1-1).

Topping, D.J., Rubin, D.M., and Schmidt, J.C., 2005, Regulation of sand transport in the Colorado River by changes in the surface grain size of eddy sandbars over multi-year timescales: Sedimentology, v. 52, p. 1133-1153.

Topping, D.J., Schmidt, J.C., and Vierra, L.E., Jr., 2003, Computation and analysis of the instantaneous-discharge record for the Colorado River at Lees Ferry, Arizona, May 8, 1921, through September 30, 2000: U.S. Geological Survey Professional Paper 1677, 118 p. [http://pubs.water.usgs.gov/pp1677].

U.S. Army Corps of Engineers, 2002, Hydrographic surveying, draft engineer manual EM 1110-2-1003: Washington, D.C., U.S Army Corps of Engineers, 506 p. [http://140.194.76.129/publications/eng-manuals/em1110-2-1003/toc.htm, last accessed September 24, 2009].

U.S. Department of the Interior, 1995, Operations of Glen Canyon Dam Final Environmental Impact Statement: Salt Lake City, Utah, Bureau of Reclamation, Upper Colorado Region, 337 p.

U.S. Geological Survey, Grand Canyon Monitoring and Research Center, 1999, Final report of the physical resources monitoring peer review panel, Ellen Wohl chairperson, November 1, 1999, 13 p.

U.S. Geological Survey, Grand Canyon Monitoring and Research Center, 2006, Colorado Mileage System [Spatial Database, GIS.BASE_GCMRC_TenthMile], 1st Revised Edition accessed June 16, 2006, at URL http://www.gcmrc.gov/products/ims

U.S. Department of the Interior, 2002, Proposed experimental releases from Glen Canyon Dam and removal of nonnative fish: environmental assessment: Salt Lake City, Utah, Bureau of Reclamation, Upper Colorado Region, 112 p., appendices.

Wohl, E., Bennett, J.P., Blum, M.D., Grant, G.E., Hanes, D.M., Howard, A.D., Mueller, D.S., Schoellhamer, D.H., and Simoes, F.J., 2006, Protocols Evaluation Program (PEPSEDS III): Final report of the physical resources monitoring peer review panel. U.S. Geological Survey Grand Canyon Monitoring and Research Center Administrative Document, $27 \mathrm{p}$.

Wright, S.A., Melis, T.S., Topping, D.J., and Rubin, D.M., 2005, Influence of Glen Canyon Dam operations on downstream sand resources of the Colorado River in Grand Canyon, in Gloss, S.P., Lovich, J.E., and Melis, T.S., eds., The state of the Colorado River ecosystem in Grand Canyon: U.S. Geological Survey Circular 1282, p. 17-31. 


\section{Figures}

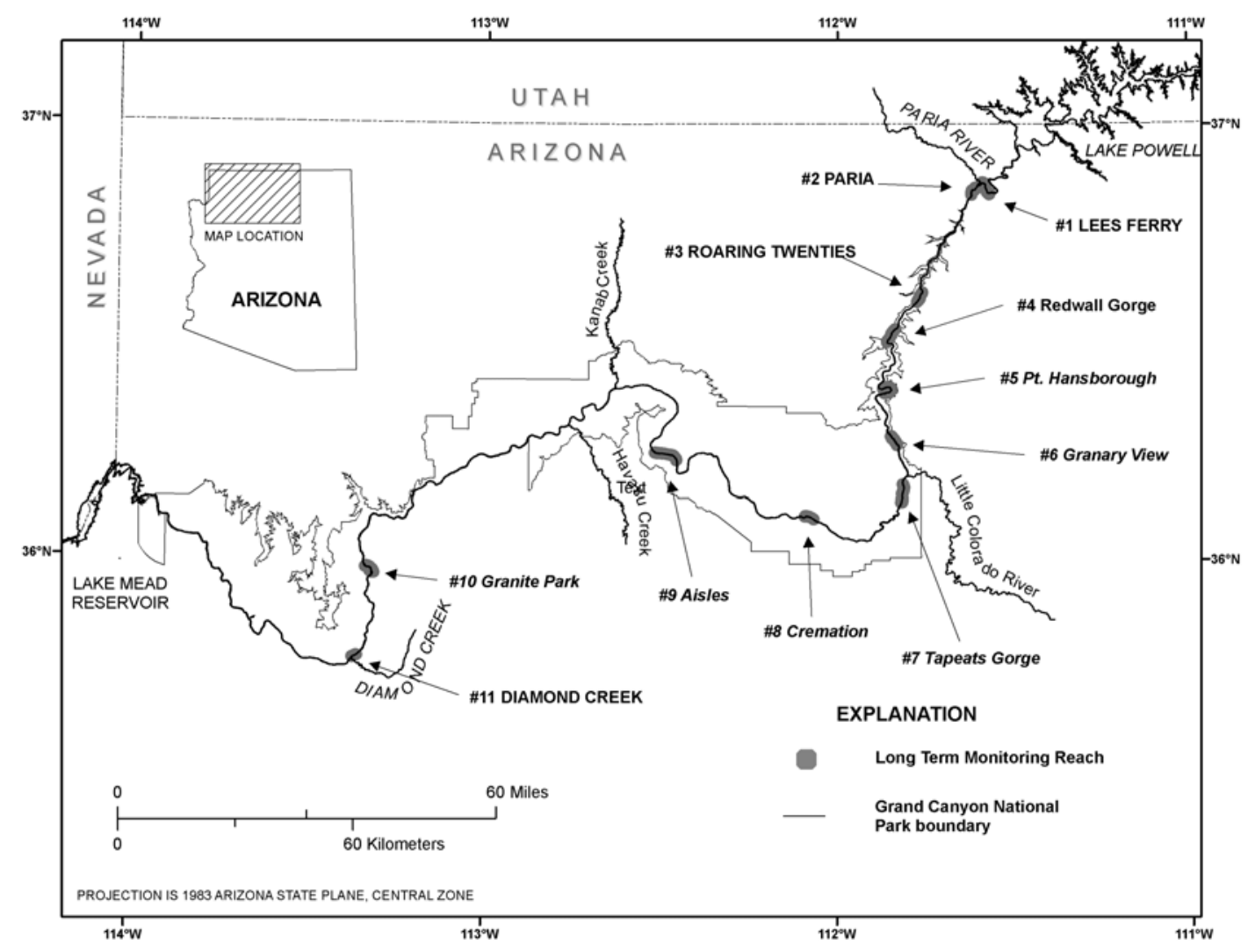

Figure 1. Map showing the locations of the long-term monitoring reaches in the Colorado River in Grand Canyon National Park, Ariz. 


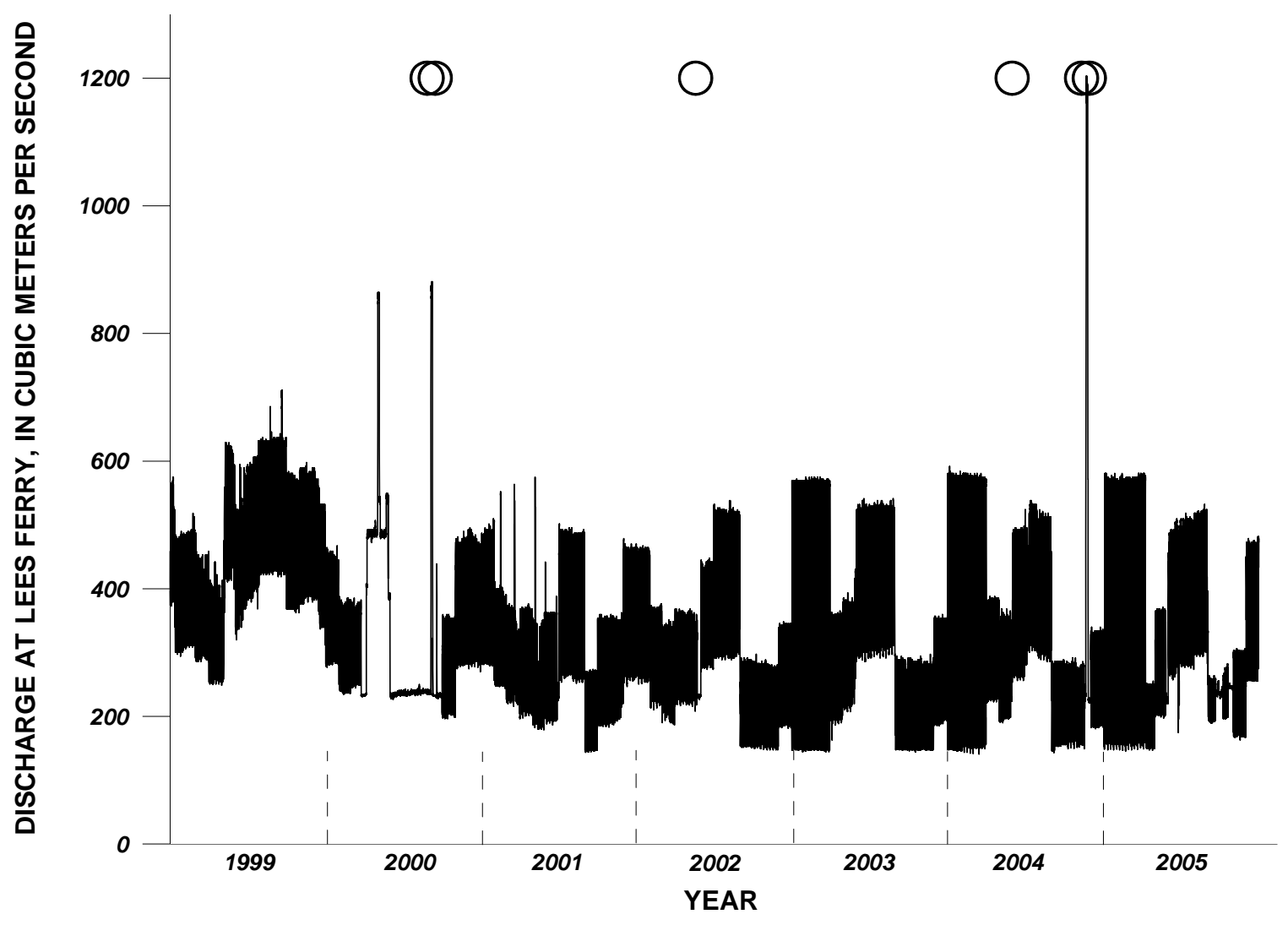

Figure 2. Discharge hydrograph from U.S. Geological Survey gaging station Colorado River near Lees Ferry (09380000) during the period of study. Dates of survey trips are show by open circles. Note the daily and seasonal fluctuations in flow volume, the Low Steady Summer Flow (LSSF) experiment in 2000 that included two powerplant capacity-flow ( 878 $\left.\mathrm{m}^{3} / \mathrm{s}\right)$ events and the high-flow experiment event $\left(1,161 \mathrm{~m}^{3} / \mathrm{s}\right)$ in November 2004. 


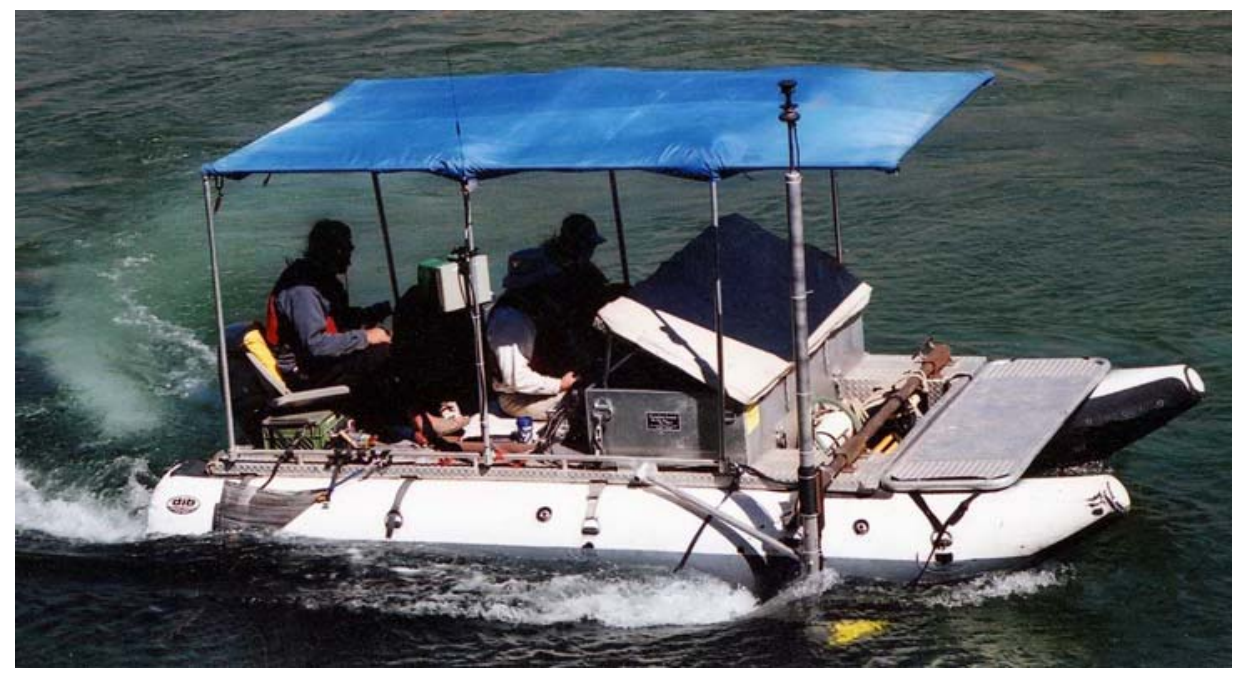

Figure 3. Photograph of the survey mini-snout raft in November 2004. 


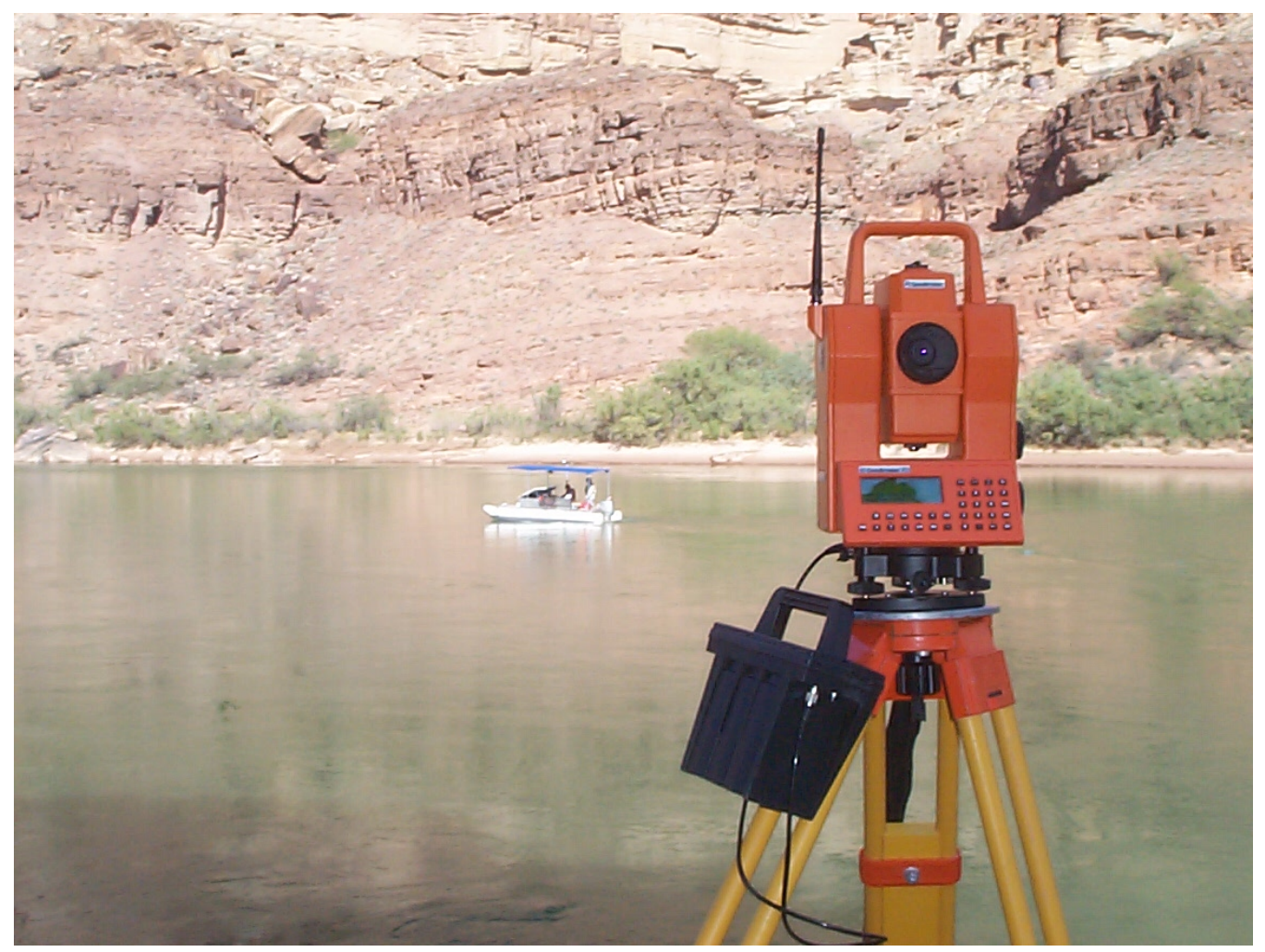

Figure 4. Photograph of the Spectra Precision Geodimeter ATS-PT robotically tracking the survey raft. 


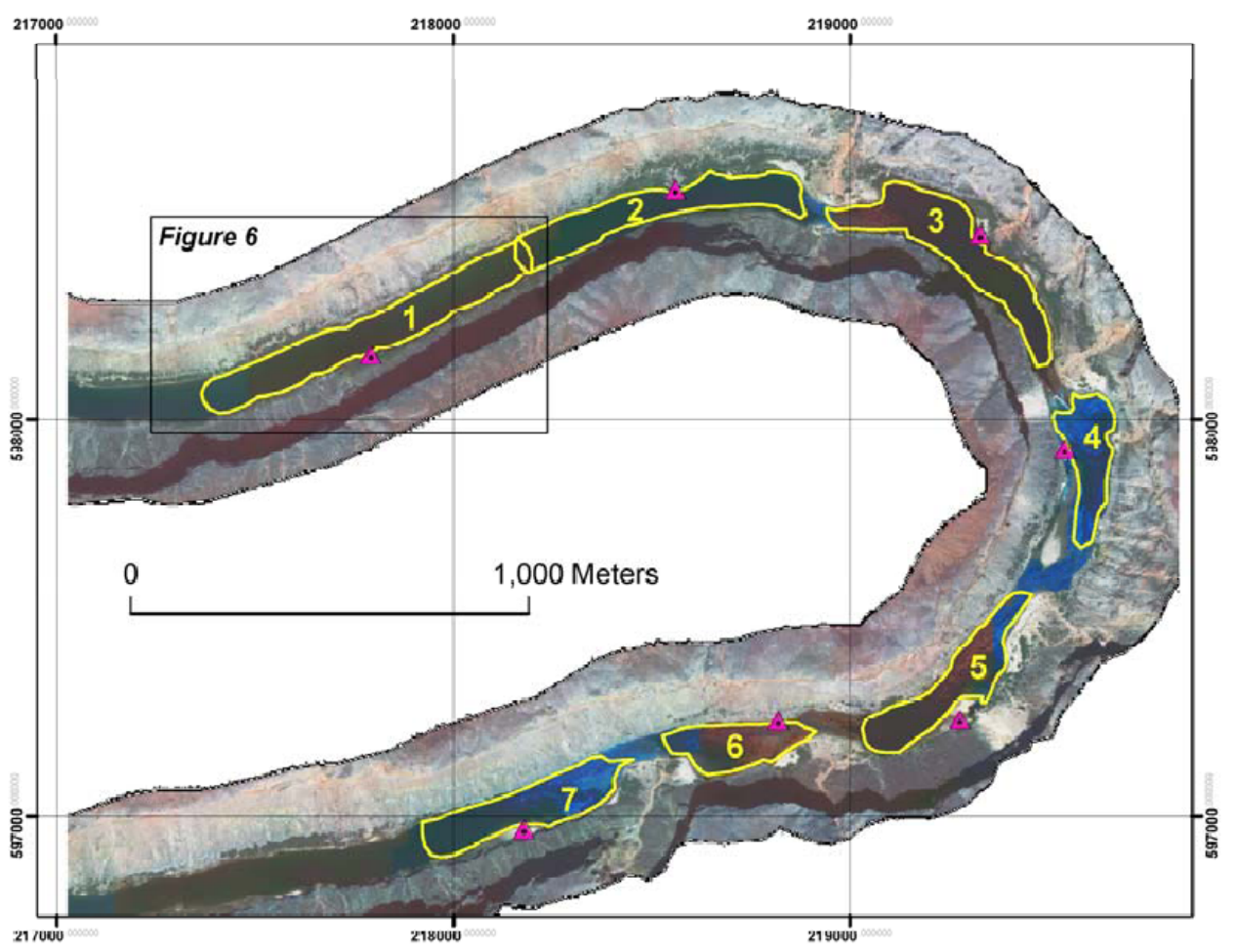

Figure 5. May 2002 orthophotography of long-term monitoring reach \#5, Point Hansborough, showing the outline of seven individual bathymetric surveys. The surveys cover an area of $407,679 \mathrm{~m}^{2}$. Shore-station locations are shown with purple triangles. Location of figure 6 is outlined by inner box. 


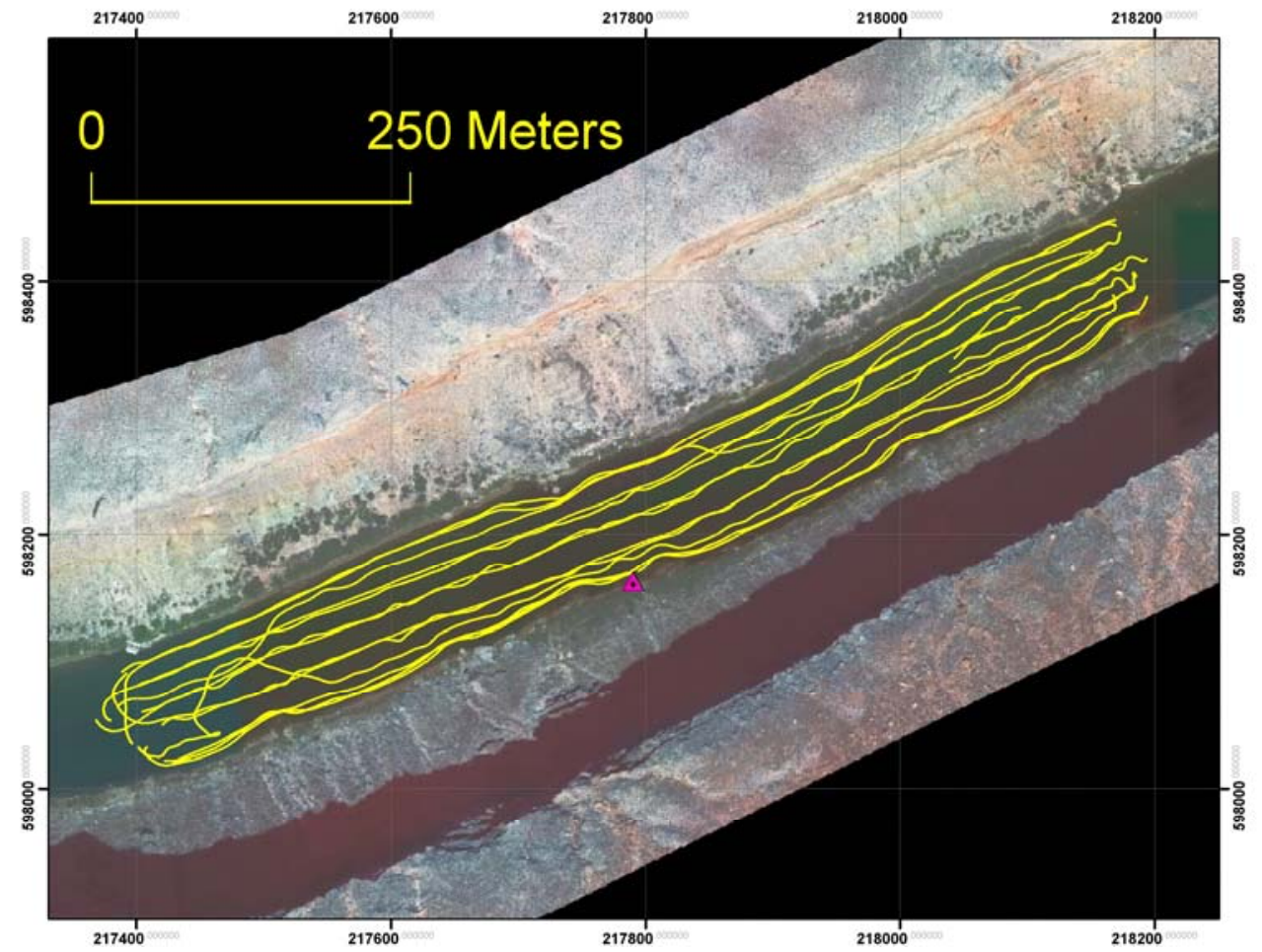

Figure 6. May 2002 orthophotography showing survey-vessel tracklines from one survey in long-term monitoring reach \#5, Point Hansborough. This is a particularly shallow portion of channel (approximately $2 \mathrm{~m}$ deep), and it required numerous sweeps to achieve fullchannel coverage. 


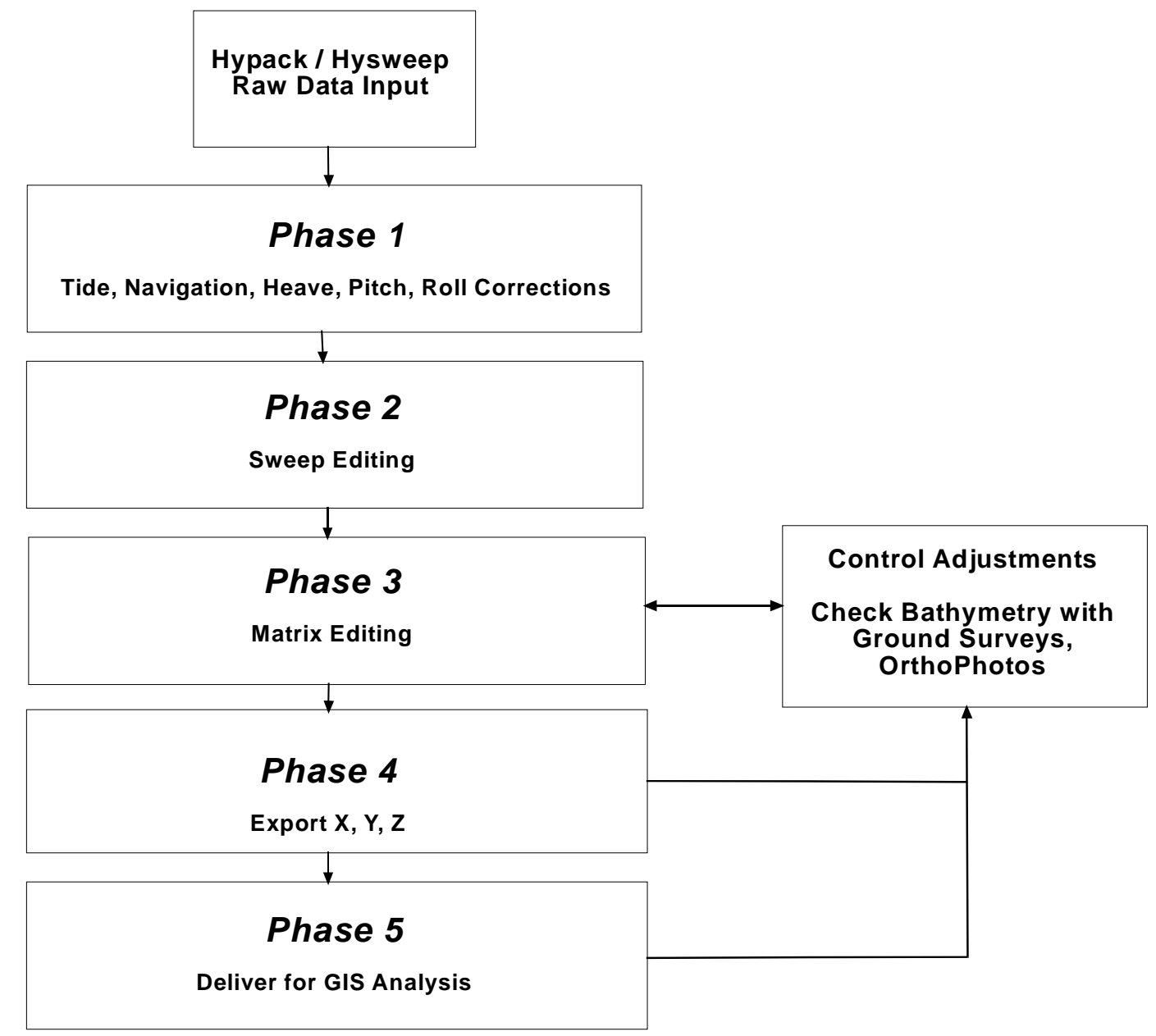

Figure 7. Processing flow chart for multibeam bathymetry. 


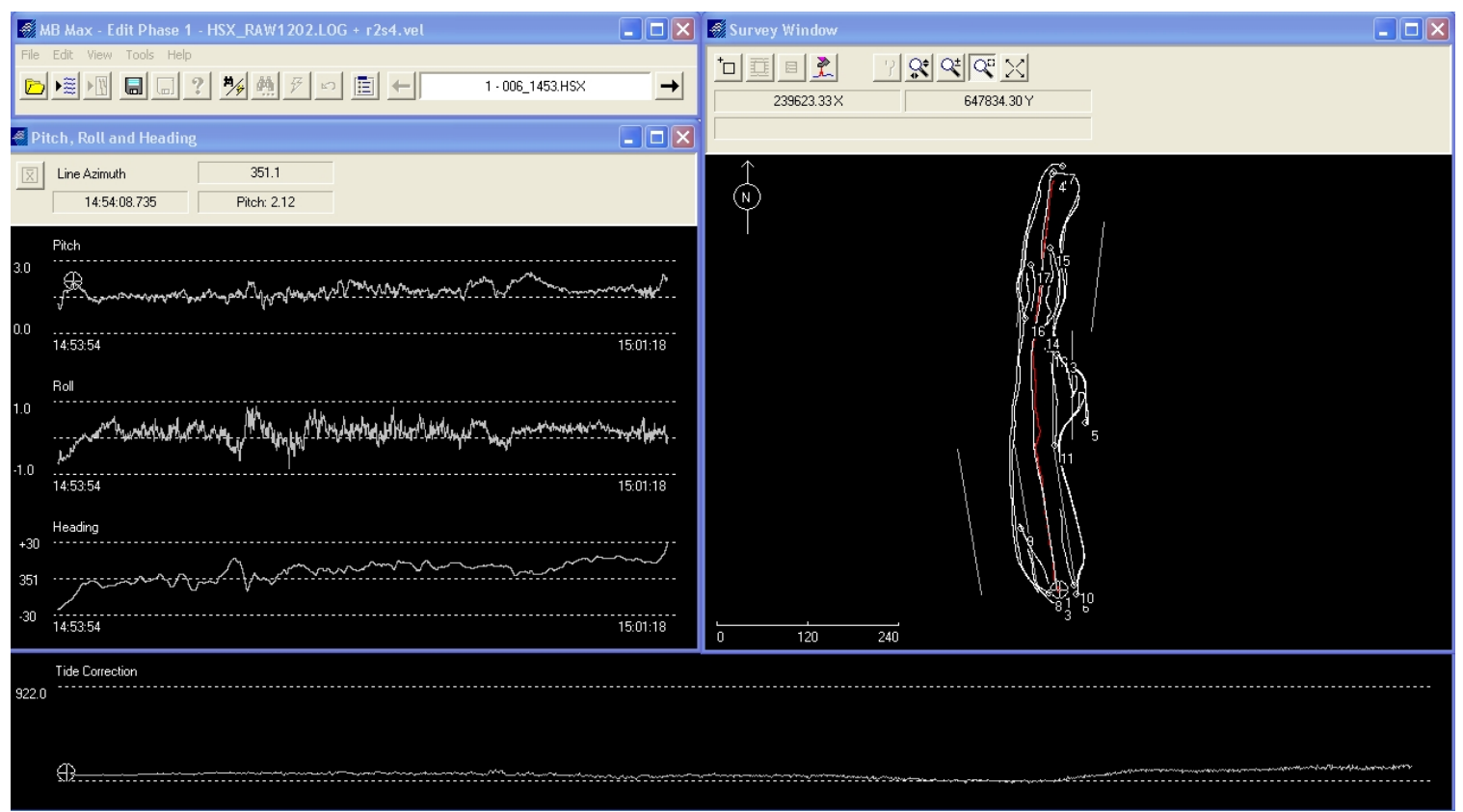

Figure 8. Screen capture of Phase-1 data processing showing survey tracklines, tide elevations, heave, pitch, and roll data windows. 


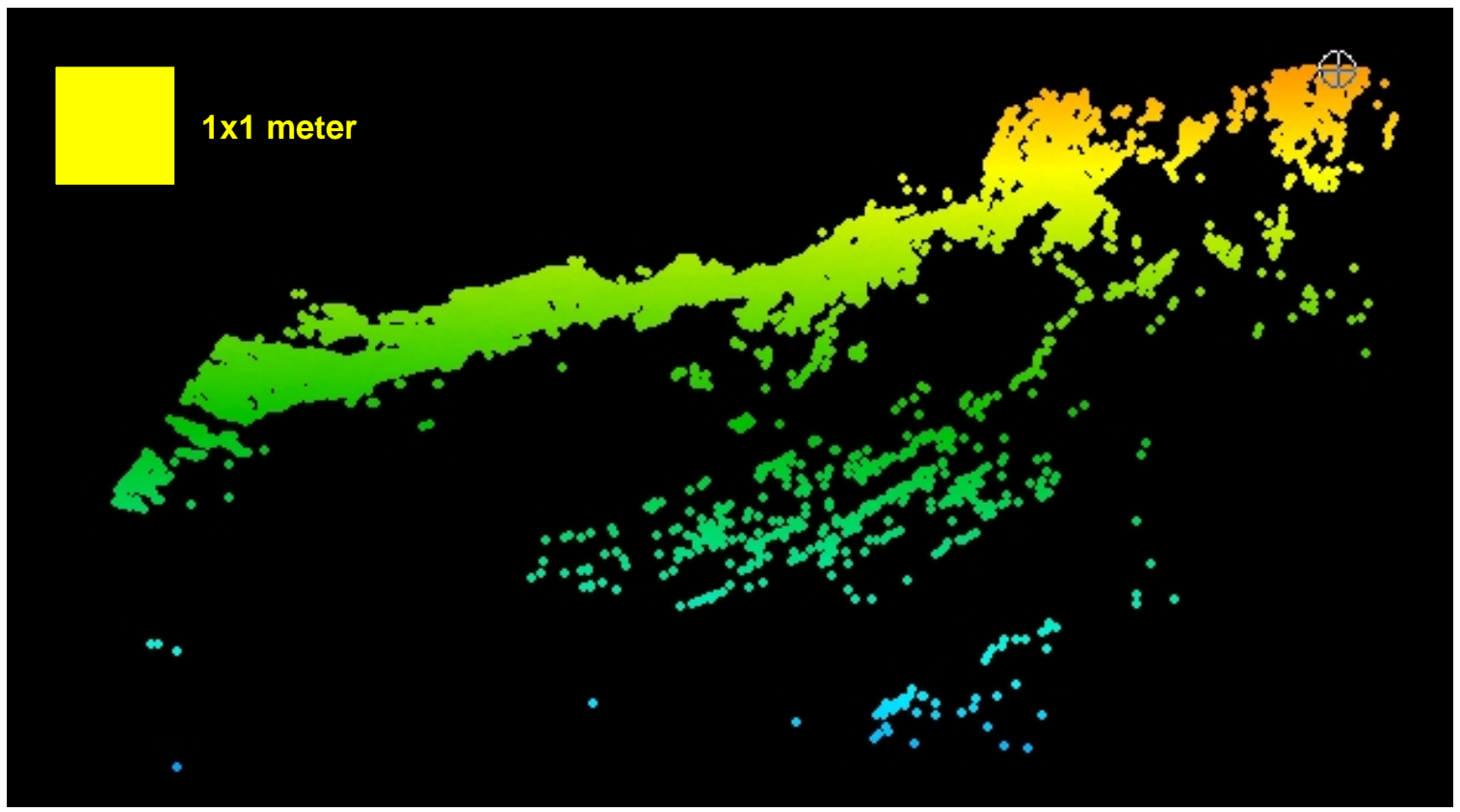

$B$

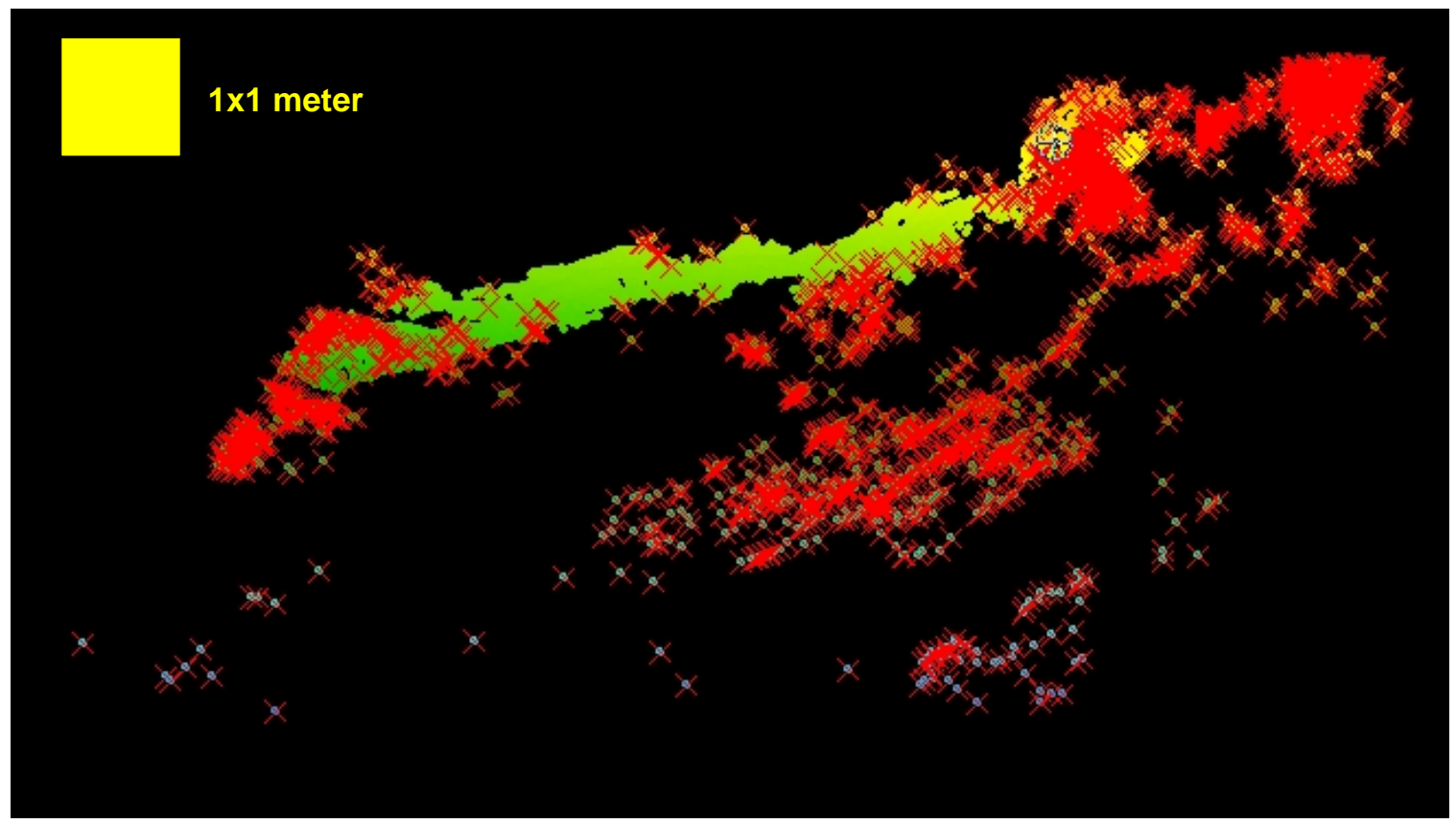

Figure 9. Screen capture of Phase-2 data processing showing cross-section view of the sweep edit window with soundings from a rocky shoreline. View shows 30 sweeps, which represents approximately 1 meter of along-track coverage, assuming a vessel velocity of $1 \mathrm{~m} / \mathrm{s}$. $A$, raw unedited soundings. $B$, edited soundings with deleted soundings highlighted by $\operatorname{red} X$. 


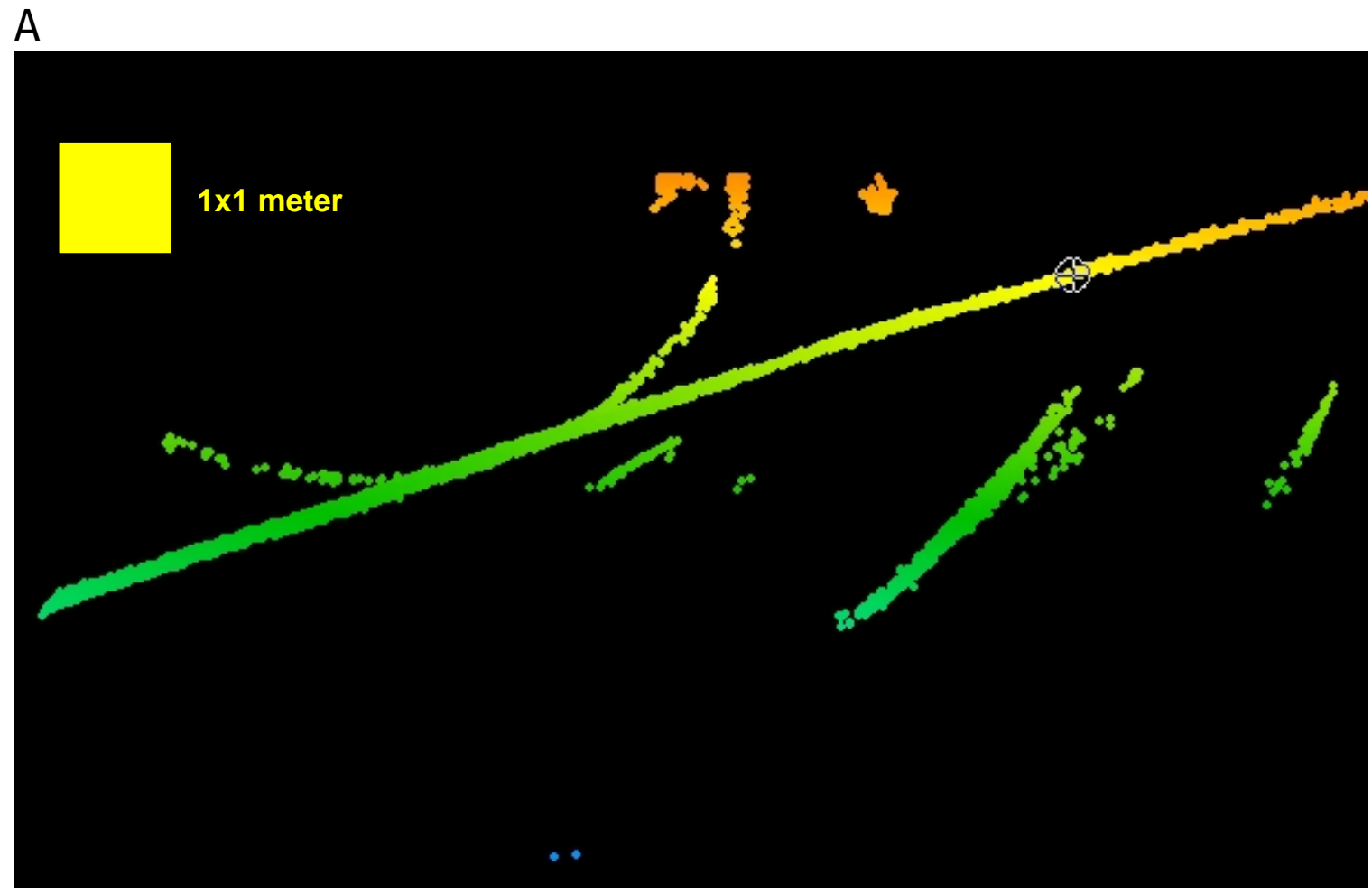

\section{$B$}

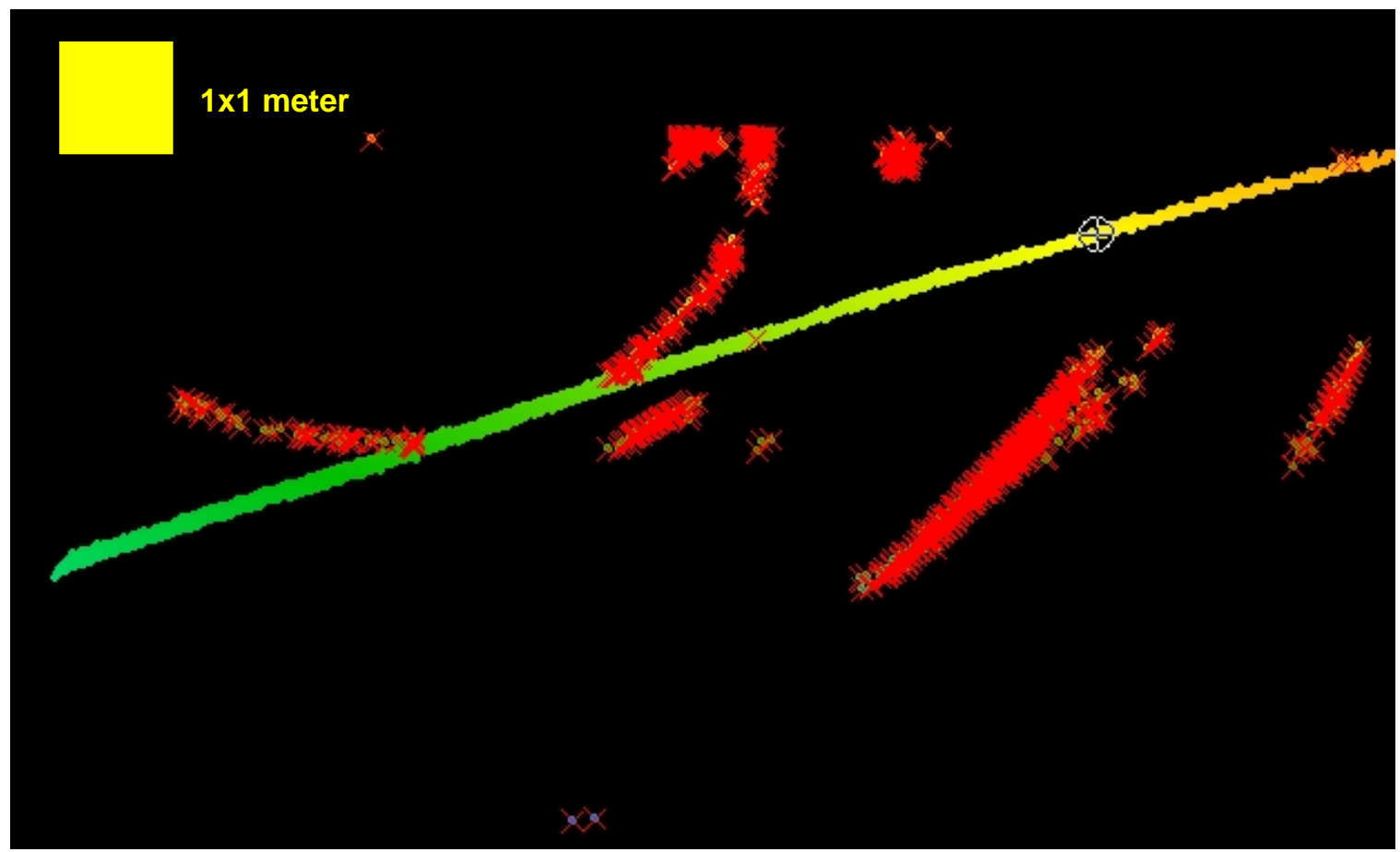

Figure 10. Screen capture of Phase-2 data processing showing cross-section view of the sweep edit window with soundings from a sandy shoreline. View shows 30 sweeps, which represents approximately 1 meter of along-track coverage, assuming a vessel velocity of $1 \mathrm{~m} / \mathrm{s}$. $A$, raw unedited soundings. $B$, deleted soundings highlighted by red $\mathrm{X}$. 
$A$

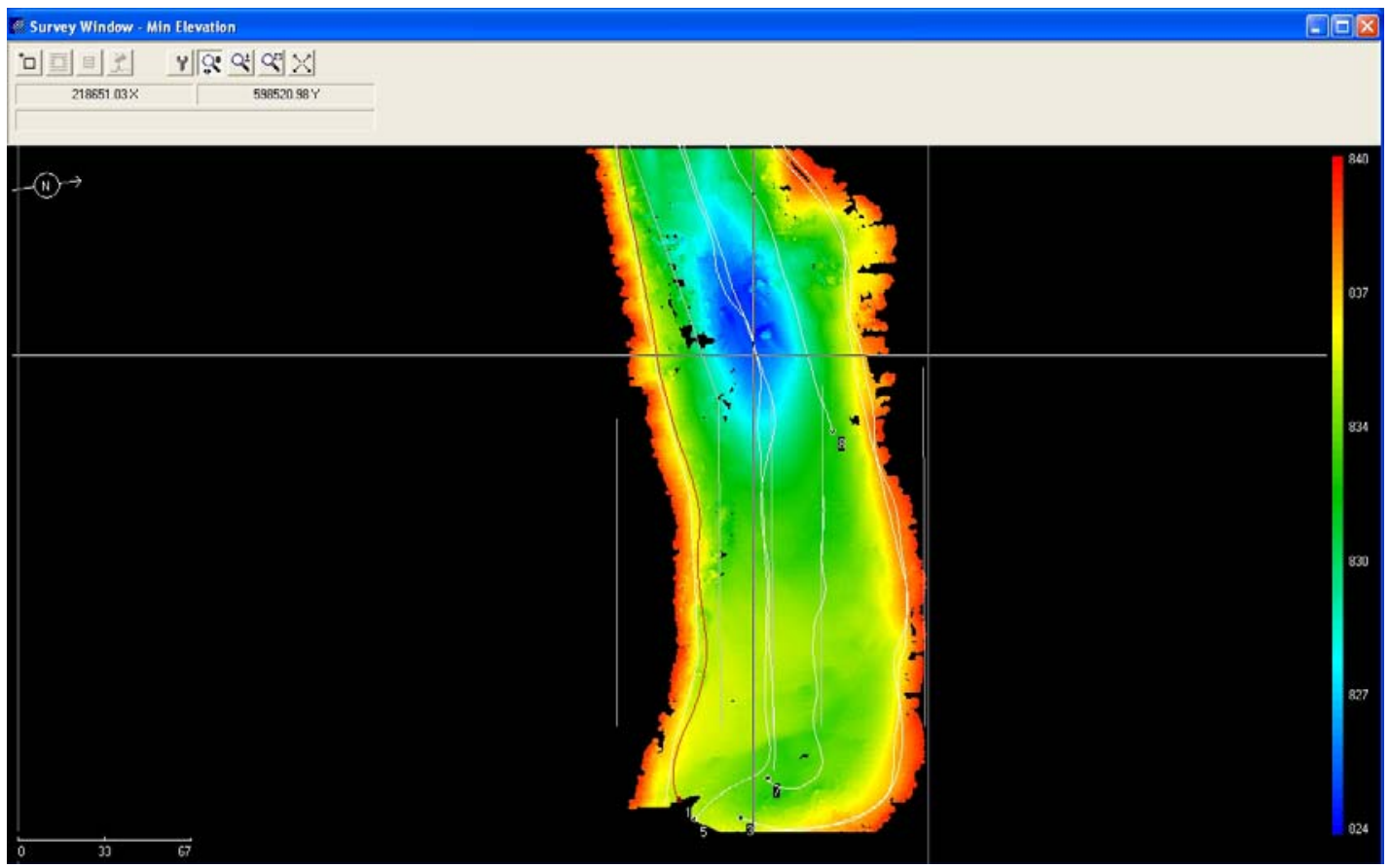

$B$

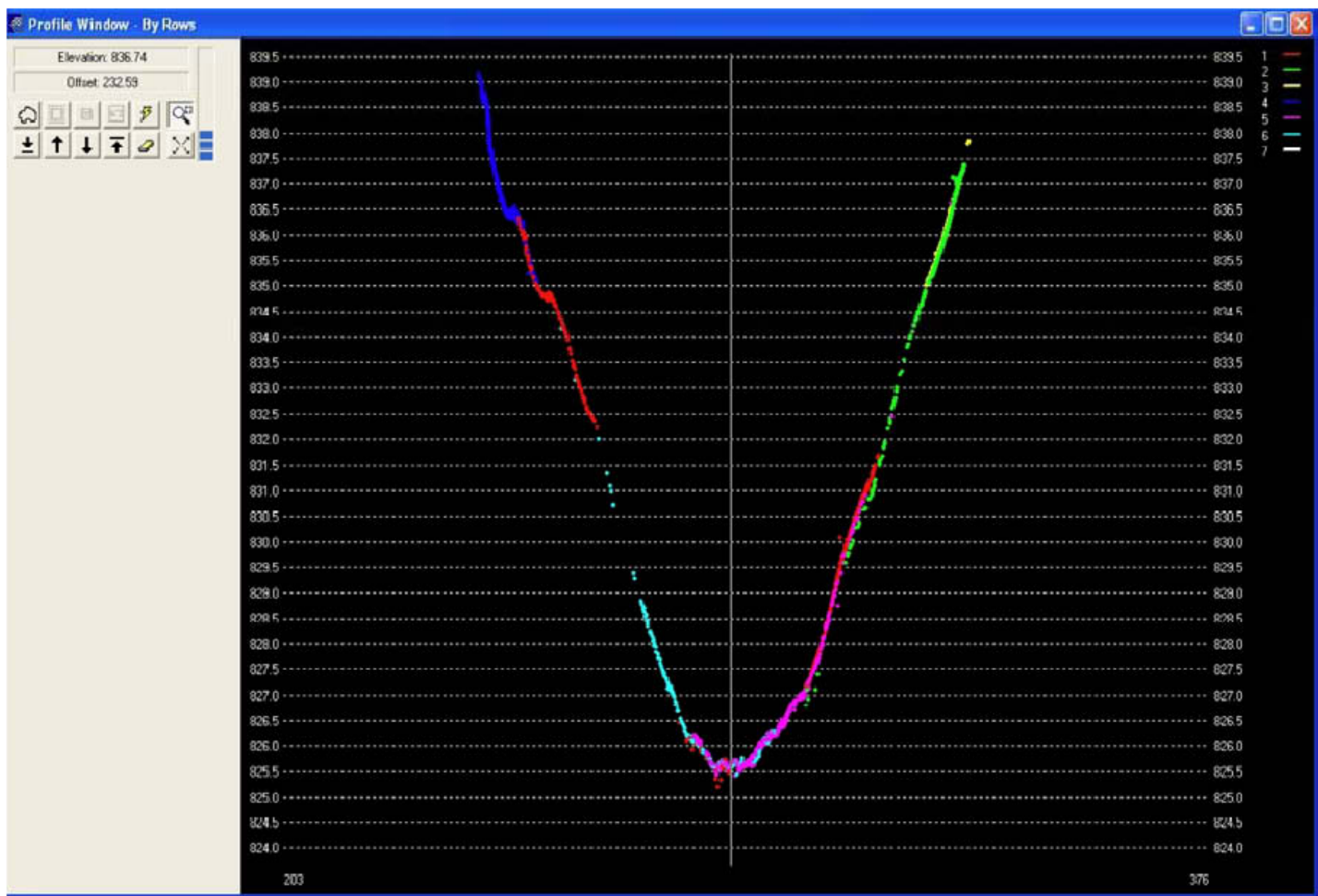

Figure 11. Screen capture of Phase-3 data processing showing map view (A) and crosssection view (B) of the matrix editor. Cross-section location is shown by the cross hairs in the map view. Colors in the cross-section view indicate each survey line. 


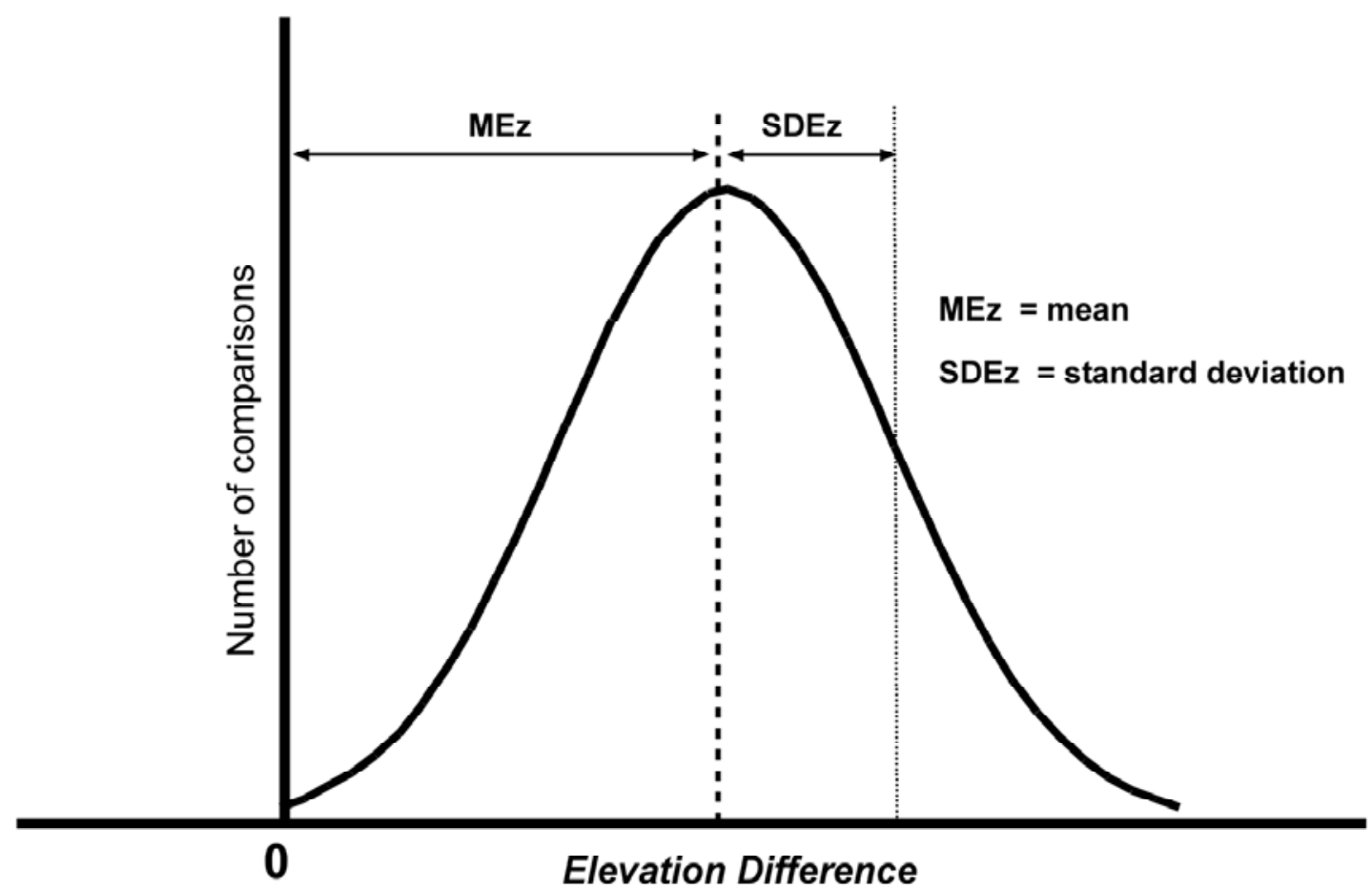

Figure 12. Diagram depicting components of cross line check root mean square uncertainty estimation. 


\section{Tables}

Table 1. Characteristics of the long-term monitoring reaches within the study area, Colorado River, Grand Canyon National Park, Ariz.

\begin{tabular}{|c|c|c|c|c|c|}
\hline \multicolumn{2}{|c|}{ Long-term monitoring reach } & \multicolumn{2}{|c|}{ River mile $^{1}$} & \multirow{2}{*}{$\begin{array}{l}\text { Average } \\
\text { channel } \\
\text { width }^{2,} \text { in } \\
\text { meters }\end{array}$} & \multirow{2}{*}{ Channel slope $^{3}$} \\
\hline Number & Local Name & Starting & Ending & & \\
\hline 1 & Lees Ferry & -2.4 & 0.0 & 123 & 0.0001 \\
\hline 2 & Paria & 1.1 & 2.7 & 113 & 0.0002 \\
\hline 3 & Roaring Twenties & 21.9 & 23.7 & 56 & 0.0016 \\
\hline 4 & Redwall Gorge & 29.4 & 32.1 & 64 & 0.0009 \\
\hline 5 & Pt. Hansborough & 42.5 & 45.5 & 82 & 0.0009 \\
\hline 6 & Granaries & 54.5 & 56.3 & 90 & 0.0003 \\
\hline 7 & Tapeats Gorge & 63.4 & 66.4 & 95 & 0.0012 \\
\hline 8 & Cremation & 86.6 & 88.1 & 64 & 0.0020 \\
\hline 9 & Aisles & 119.3 & 123.3 & 65 & 0.0010 \\
\hline 10 & Granite Park & 207.7 & 209.2 & 72 & 0.0013 \\
\hline 11 & Diamond Creek & 224.8 & 225.6 & 66 & 0.0002 \\
\hline
\end{tabular}

${ }^{1}$ Based on the river-mile centerline (U.S. Geological Survey, 2006) downstream from Lees Ferry (river mile 0), in Grand Canyon National Park except, the Lees Ferry Reach, which is in Glen Canyon National Recreation Area.

${ }^{2}$ At $227 \mathrm{~m}^{3} / \mathrm{s}$, average based on cross-section data from Magirl and others (2008).

${ }^{3}$ Based on measured water-surface elevations at a steady discharge of $227 \mathrm{~m}^{3} / \mathrm{s}$. 
Table 2. Summary of types of data collected on survey trips from 2000 to 2004.

\begin{tabular}{|l|l|l|l|l|}
\hline $\begin{array}{l}\text { Survey } \\
\text { Date }\end{array}$ & Reach & Bathymetry & Remote Sensing & $\begin{array}{l}\text { Survey Controll } \\
\text { Ground Truth }\end{array}$ \\
\hline $\begin{array}{l}\text { Aug. } \\
2000\end{array}$ & $2,4,5,7$ & $\begin{array}{l}\text { Multibeam/ } \\
\text { singlebeam }\end{array}$ & LIDAR & Total station \\
\hline $\begin{array}{l}\text { Sept. } \\
2000\end{array}$ & $2,4,5,7$ & $\begin{array}{l}\text { Multibeam/ } \\
\text { singlebeam }\end{array}$ & LIDAR & Total station \\
\hline $\begin{array}{l}\text { May } \\
2002\end{array}$ & $1-11$ & Multibeam & Photogrammetry & Total station \\
\hline Jun. 2004 & $2-8$ & Multibeam & LIDAR & Total station \\
\hline $\begin{array}{l}\text { Nov. } \\
2004\end{array}$ & $2-7$ & Multibeam & LIDAR & Total station \\
\hline $\begin{array}{l}\text { Dec. } \\
2004\end{array}$ & $2-7$ & Multibeam & LIDAR & Total station \\
\hline
\end{tabular}


Table 3. Bathymetric survey equipment configuration for each survey trip.

\begin{tabular}{|l|l|l|l|l|l|}
\hline $\begin{array}{c}\text { Survey } \\
\text { date }\end{array}$ & Navigation & \multicolumn{1}{|c|}{ Sonar } & Motion sensor & Heading & Software \\
\hline Aug. 2000 & $\begin{array}{l}\text { Range- } \\
\text { Azimuth }\end{array}$ & $\begin{array}{l}\text { Reson 8124 / } \\
\text { Innerspace 448 }\end{array}$ & TSS DMS05 & KVH Fluxgate & Hypack \\
\hline Sept. 2000 & $\begin{array}{l}\text { Range- } \\
\text { Azimuth }\end{array}$ & $\begin{array}{l}\text { Reson 8124 / } \\
\text { Innerspace 448 }\end{array}$ & TSS DMS05 & KVH Fluxgate & Hypack \\
\hline May 2002 & $\begin{array}{l}\text { Range- } \\
\text { Azimuth }\end{array}$ & Reson 8125 & TSS DMS05 & KVH Gyrotrac & Hypack \\
\hline Jun. 2004 & $\begin{array}{l}\text { Range- } \\
\text { Azimuth }\end{array}$ & Reson 8125 & TSS MAHRS & TSS MAHRS & Hypack \\
\hline Nov. 2004 & $\begin{array}{l}\text { Range- } \\
\text { Azimuth }\end{array}$ & Reson 8125 & TSS MAHRS & TSS MAHRS & Hypack \\
\hline Dec. 2004 & $\begin{array}{l}\text { Range- } \\
\text { Azimuth }\end{array}$ & Reson 8125 & TSS MAHRS & TSS MAHRS & Hypack \\
\hline
\end{tabular}


Table 4. Summary of estimated depth-uncertainty assessment for each survey trip.

\begin{tabular}{|l|c|c|c|c|c|}
\hline \multicolumn{1}{|c|}{ Survey Date } & MEz (cm) & SDEz (cm) & RMSUz (cm) & MAUz (cm) & $\mathbf{n}^{\mathbf{1}}$ \\
\hline Aug. 2000 & 1.39 & 8.8 & 17.4 & 7.1 & 16,830 \\
\hline Sep. 2000 & -4.7 & 9.1 & 20 & 8.2 & 21,743 \\
\hline May 2002 & 0.8 & 7.4 & 14.6 & 5.6 & 19,514 \\
\hline June 2004 & -3.0 & 6.3 & 13.7 & 5.6 & 21,585 \\
\hline Nov. 2004 & -0.1 & 4.8 & 9.4 & 3.8 & 28,996 \\
\hline Dec. 2004 & 0.02 & 5.0 & 9.8 & 3.8 & 18,661 \\
\hline
\end{tabular}

${ }^{1} \mathrm{n}=$ number of points included in the uncertainty assessment. 
This page intentionally left blank. 


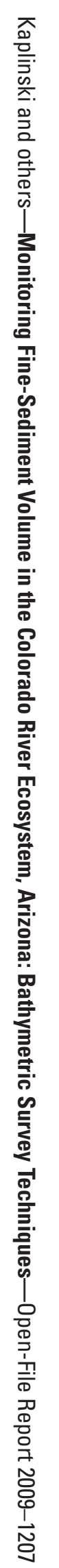

